INSIGHTS INTO REGIONAL DEVELOPMENT

ISSN 2669-0195 (online) http://jssidoi.org/IRD/ 2020 Volume 2 Number 4 (December) http://doi.org/10.9770/IRD.2020.2.4(1)
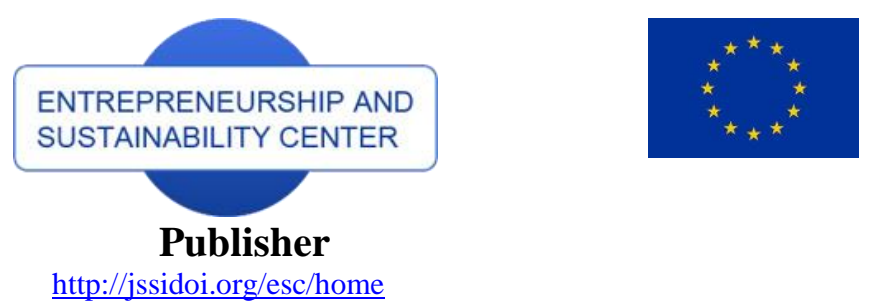

\title{
FISCAL POLICIES, PUBLIC INVESTMENTS AND WELLBEING: MAPPING THE EVOLUTION OF THE EU*
}

\author{
Massimiliano Mazzanti ${ }^{1}$, Matteo Mazzarano ${ }^{2}$, Andrea Pronti ${ }^{3}$, Marco Quatrosi ${ }^{4}$ \\ 1,2,3,4 Department of Economics and Management, University of Ferrara, Via Voltapaletto, 1144121 Ferrara, Italy

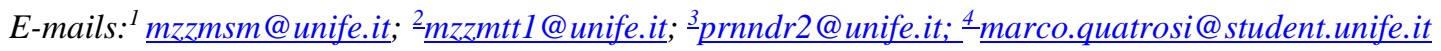

Received 18 June 2020; accepted 27 August 2020; published 30 December 2020

\begin{abstract}
The European Union faced several crises in the last twenty years that destabilized its macroeconomic equilibrium and development capacity. Standard economic methodologies were capable of neither predicting nor completely solving these crises through appropriate investments. To understand the overall development performance, the well-known Human Development Index (HDI) is the most widely deployed conceptual framework. In this article, we look at the components of welfare dynamics in the EU by examining socio-economic performance. Through a 'beyond gross domestic product (GDP)' approach, we analyse public expenditures, especially focusing on the pillars of growth and socio-economic development: education, health, and total R\&D. We believe that convergence policies and sustainability policies should together be given a greater role within the EU agenda. They are necessarily interlinked with each other and with the common welfare, the true objective of public policy. European strategies on the key human development pillars were heterogeneous during the last decades. The post 2009 recession was characterized by non-expansionary measures that have undermined development in most countries. Due to the lack of a robust investment patterns towards human and sustainable development, European

\footnotetext{
* The research is conceptually related to the activities of the European Topic Centre on Waste, materials and the Green Economy (ETC WMGE, European Environment Agency). It is also within the research activities of the 2018-2022 UNIFE project on Circular economy, Innovations and SMEs funded by MIUR Italian ministry under the 'Departments of excellence' programme, and the activities of the related CERCIS research centre on Circular Economy, Innovation and SMEs.
}

All responsibilities remain upon the authors

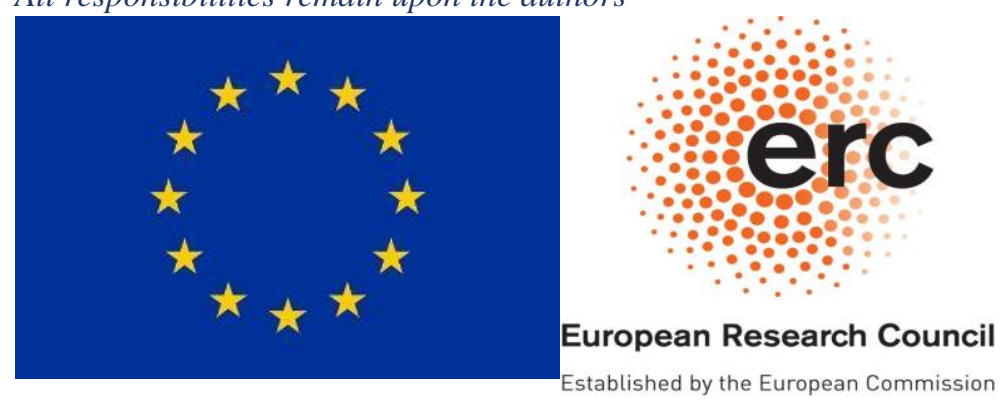




\section{INSIGHTS INTO REGIONAL DEVELOPMENT}

ISSN 2669-0195 (online) http://jssidoi.org/jesi/

2020 Volume 2 Number 4 (December)

http://doi.org/10.9770/IRD.2020.2.4(1)

countries were not fully prepared to tackle the COVID-19 shock. Growth and development figures were already gloomy in 2019 and the years before. The hope is that this lesson is useful to create a solid society and economic system for possible future crises.

Keywords: fiscal policies; public investments; wellbeing; EU

Reference to this paper should be made as follows: Mazzanti, M., Mazzarano, M., Pronti, A., Quatrosi, M. 2020. Fiscal policies, public investments and wellbeing: mapping the evolution of the EU. Insights into Regional Development 2(4): 725-749.

http://doi.org/10.9770/IRD.2020.2.4(1)

JEL Classifications: Q01

\section{Introduction}

Is the current systemic crisis a new type of shock? Yes and no. Its global diffusion is certainly a partial novelty. On the other hand, the evolution of human societies has always been characterized by shocks (pandemics, pestilences, wars, capitalist recessions, etc.), which generate destructive and creative effects on the socioeconomic side or even radical changes and require political responses in the short and medium term (Krugman, 2018). Economic development and socio-economic patterns are highly nonlinear and heterogeneous: policies, wars, and recessions act as structural breaks and can modify the patterns that link the environmental, social, economic, and technological spheres. Smoothness and linearity are specific cases within a very nonlinear historical development that has largely been driven by crises and policy responses to crises (Musolesi and Mazzanti, 2014; UNIDO, 2018).

The current COVID crisis is thus partially new. The key point is to reflect upon what happened before the crisis in terms of investments in some key public goods that support human development and growth, namely, education, R\&D and health. Were we investing enough? Were investments in sustainability (Hamilton and Hartwick, 2005; Spinozzi and Mazzanti, 2018) on an increasing or decreasing trend?

Those questions are relevant because the current crisis comes exactly 10 years after the previous crisis. It is thus relevant to analyse how the capacity to tackle the current socio-economic and health crisis is affected by the investments we made in between the two crises. Societies and economic systems could be more fragile now than before 2009 due to the disinvestments that may have occurred in some states to 'adjust' public budgets, following so-called expansionary austerity policies ${ }^{\dagger}$. It is therefore also relevant to reflect on the possible policy changes (fiscal, monetary, innovation, human development, environmental) that the current crisis calls for.

We had a large, typical capitalistic recession due to excess supply over demand - fuelled by financial globalization - in 2008-2009. Unlike the USA, Europe did not react with the appropriate mix of monetary and fiscal policies. Thanks to Mario Draghi's 'whatever it takes' policy, European growth was sustained over 2013-

\footnotetext{
$\dagger$ In late 2019, the euro area budget balance showed a $1 \%$ deficit, in the face of gloomy growth and unemployment figures. The USA presented a $4.6 \%$ deficit before the coronavirus crisis and soon reached $12 \%$ in March 2020, while the EU debated the amount and type of deficit (eurobonds, coronabonds, etc.) to take on. An interesting view, which is possibly the only pragmatic way out, is offered by Jordi Gali (https://voxeu.org/article/helicopter-money-time-now), who proposes that "there is an alternative to a strategy based on higher taxes and/or more government debt in order to finance such an emergency fiscal programme, albeit one that has remained a taboo among most economists and policymakers - namely, direct, unrepayable funding by the central bank of the additional fiscal transfers deemed necessary, an intervention commonly known as 'helicopter money".
} 
INSIGHTS INTO REGIONAL DEVELOPMENT

ISSN 2669-0195 (online) http://jssidoi.org/jesi/ 2020 Volume 2 Number 4 (December)

http://doi.org/10.9770/IRD.2020.2.4(1)

2019 , but at the end of 2019, unemployment was still at high levels, inflation was dramatically low at under $2 \%$, and the EU's sustainable debt ratio was at approximately $80 \%$ of GDP. Growth and macroeconomic fundamentals were neither good nor stable before the coronavirus crisis occurred. Fiscal policy mismanagement ${ }^{\S}$ has been especially relevant in the EU. The only 'benefit' of the lack of proper fiscal expansionary measures is the low debt, which could allow for the expansion of fiscal policy in a very substantial way, with inflation being only a pseudo-problem now. Instead, a vicious circle of Japanese-style deflation is the threat to be dealt with.

As one example among others, the green recovery packages that were discussed at the G20 in April 2009 were soon abandoned. The G20 had proposed these packages - which were heterogeneously implemented by countries - to address the downturn as a sort of global Green New Deal, with specific reference to the technological effects of ecological tax reforms (UNEP, 2009).

In 2019, after 10 years of low growth and fears of secular stagnation, the EU and key players such as Germany were discussing Green New Deals to sustain demand, which involve investments in green R\&D, infrastructure, and green human capital. In addition, the EU Circular Economy Strategy (EC, 2015, 2020) highlights innovative business models and explicitly monitors circular economy innovations, such as 'patents related to recycling and secondary raw materials', at the macroeconomic level (Eurostat, 2020). In a different economic and political cycle, a proposal for a Green New Deal originated in the US in 2018. The non binding proposal, known as the 'Ocasio-Cortez resolution' of the Democratic Party, was defeated in the Senate in 2019. Those Green New Deal ideas are necessary. Governments could extend such proposals into a Wellbeing New Deal, coherent with a broad sustainability and human development perspective that considers the necessity of a 'just transition' as well. Against this background, this paper analyses the macroeconomic trends that are most relevant for sustainability ${ }^{* * *}$ from a medium- to long-run perspective, which can be useful in helping us 'understand the past to change the future'.

\section{Sustainable development and wellbeing: a brief background of the concept over history}

By acknowledging the human impact on the environment and the extent to which natural capital affects economic development, the first United Nations "Conference on the environment and sustainable development" in 1972 identified the key principles that led to the definition of the Human Development Index in 1980 and sustainable development at the end of the 1980s. This was the background for the new emphasis placed on sustainable development in that period to correct the environmental (and social) distortions of market-driven economic growth. Macroeconomic thinking was at the centre of the sustainable development idea, formalized by the Brundtland commission in 1987 and five years later at the Rio convention. The 1990s also witnessed the birth of EU waste management and disposal policies, the background for the waste prevention/circular economy framework.

A focus on the interconnections between sustainable and human development (e.g., the key role of human and social capital) has contributed to the development of a fruitful, broad view of development strategies. The

\footnotetext{
$\$$ Related to international competition in financial and goods market, a lack of unionization, flexible labour markets, low oil prices, a lack of very stringent environmental policy, a lack of expansionary fiscal policy, etc.

$\S$ In December 2019, Germany presented a budget balance in surplus $(+1 \%)$ in the face of high unemployment levels in Europe. The US policy mix was pragmatic (a budget deficit of $4.6 \%$ in December 2019, following deficits of 8-10\% over 2010-12). Before the crisis, France (with a deficit of 3.2\%) was the only country in the EU to follow a different model of fiscal policy from the German one. The surplus on the German current account balance (+7\% in 2019!) is more a consequence of its fiscal surplus than of German competitiveness. Germany itself was suffering from its export-biased growth model: its pre-virus growth was $0.6 \%$.

** We do not consider here the issue of environmental and economic sustainability. We refer the reader to the brand-new EEA Report launched in April 2020 (EEA, 2020), in which some SEEDS and University of Ferrara members appear as contributors.
} 


\section{INSIGHTS INTO REGIONAL DEVELOPMENT}

ISSN 2669-0195 (online) http://jssidoi.org/jesi/

2020 Volume 2 Number 4 (December)

http://doi.org/10.9770/IRD.2020.2.4(1)

economic approach to the concept of sustainable development revolves around substitutability between natural and produced capital, which gives rise to the identification of weak or strong sustainability (Neumayer, 2014). The macroeconomics of sustainable development literature points to the role of capital accumulation in all its forms (natural, human, manmade, social) through investments and provides theoretical rules for the sustainable management of renewables and non-renewables (e.g., the Hartwick rule or golden rule to properly manage rents to set a constant pattern of investments). Genuine savings measures, especially some used by the World Bank, have originated from the Hartwick rule for the reinvestment of rents from the depletion of natural capital into reproducible forms of capital. The 'management of resources' literature widely debates how to achieve patterns of sustainability, including related ethical and equity considerations.

From the neo-Keynesian perspective, Heyes (2000) attempted to incorporate the environmental constraint in a standard IS-LM model. Through this IS-LM-EE framework, he showed that overlooking the environment when planning economic development is a strategy for serious breakdown and that sustainable economic development needs to be supported by costly but necessary control measures and by upgraded economic standards (Sim, 2006).

Reconnecting to the Limits to Growth and to the legacy of Herman Daly's macroeconomic theory, ecological economists and social scientists introduced the theme of degrowth to achieve the objectives of a new sustainability, namely, a lighter, fairer, more inclusive society. The concept has stimulated a broad inter- and multidisciplinary debate and has offered an opportunity to integrate theories.

In this setting, the role played by institutions must be considered. As Van den Bergh (2011) argued, while, on the one hand, GDP growth is not a robust indicator of social welfare, and so it is possible to completely ignore it, on the other hand, GDP degrowth is neither necessary nor sufficient for sustainability. The correlations between GDP and welfare or between GDP and environmental impact are not constant and fixed over time. According to the author, it should be stressed that being against GDP or against unconditional GDP growth is not the same as being against growth. Innovation and knowledge are crucial to create a sustainable, inclusive society that is oriented toward human development, where GDP is a means of achieving objectives, not the objective itself.

While innovation was not a primary factor in the sustainable development debate, it entered the scientific and policy arena in the late 1990s, mainly through the assessment of the hypothesis that environmental policies may induce techno-organizational innovations that the market on its own would hardly support. Over time, the notion of innovation has broadened to include eco-innovations, sustainable innovations, frugal innovations, etc., with reference to the complementarity between innovation and human resources (knowledge). This reconciles the innovation framework with economic growth theory and economic development studies.

Overall, the macroeconomic policies and strategies that the EU is shaping, with special emphasis on the Green New Deal, should be informed by the historical evolution of sustainable development perspectives. Investments in social and environmental sustainability, and investments in general, are the pillar of a strategy aimed at achieving increasing wellbeing. The integration of green investments and environmental policies with innovation/knowledge investments and the fiscal/monetary policy framework is crucial to fully pursuing the various interconnected development goals. The Green/Wellbeing New Deal should be a way to generate a turning point in the path towards sustainability for European societies and economic systems, including in the face of other shocks (economic dislocations, resource scarcities, wars, the coronavirus pandemic) that demand appropriate macroeconomic responses through investments.

Investment growth is a cycle that requires economic growth. New resources are collected via taxes and then redistributed. If economic growth is low or higher taxation is not possible to implement, deficit spending is required. In turn, maintaining the status quo or enacting changes in public expenditure affect the political cycle. This was the case in Southern European countries. As we will show further on, this policy paid off less than in 
INSIGHTS INTO REGIONAL DEVELOPMENT

ISSN 2669-0195 (online) http://jssidoi.org/jesi/

2020 Volume 2 Number 4 (December)

http://doi.org/10.9770/IRD.2020.2.4(1)

their northern counterparts, where growth was nourished by trade surpluses. This instability of macroeconomic accounts affected the divergences of policies.

In this paper, as a first step, various cross-country comparisons will be presented, taking as reference a set of key fiscal and economic indicators, including innovation, over the main EU economies, which may provide food for thought on the heterogeneity of their performance. Different economic-fiscal models could emerge on the basis of an economic equilibrium that has partially recovered from the 2008 downturn but still presents critically high unemployment, unstable GDP growth and below-target inflation (Krugman, 2018). The lack of a sustainable fullemployment dynamic largely depends on within-EU socio-economic divergences and disequilibria in economic accounts. These divergences and disequilibria are largely driven by trade surpluses/deficits, public budgets and debt, R\&D expenditures - in other words, a general lack of fiscal coordination and homogeneity, in addition to the well-known 3\% deficit/GDP target. The analyses below are a way to describe the current situation. This ex post portrait covering the past two decades is useful for discussions - with the help of complementary ex ante modelling exercises - of the future dynamics of EU fiscal sustainability, starting from the current national fiscal models, heterogeneity, deficiencies, and criticalities. This paper will provide evidence based on cross-country comparisons of various indicators and country-specific analysis of the dynamics of these indicators from Eurostat datasets updated to 2019.

We present indicators on education, research and health as a summary of the most relevant evidence underlying different patterns of investment amongst EU countries. The set of variables that the paper analyses is limited to those that mainly influence citizens' wellbeing. However, the paper tries to capture the essential facts that drive the macroeconomic variables influencing economic development, which is the central framework wherein environmental, social and fiscal sustainability is integrated. One of the key messages is that environmental and social sustainability are embedded and dependent on a higher-level macroeconomic framework, the short- and medium-term dynamics of which need to be described and understood. We first present the main macroeconomic and fiscal dynamics, and then the analysis will proceed with a more detailed examination of key indicators and substantive factors related to wellbeing, considering the investments in economic growth and development (health, education, innovation). Finally, we conclude by providing some highlights.

\section{Public Governance and Wellbeing}

Wellbeing can be disentangled into five dimensions related to the fulfilment of a certain set of psychological, material and social needs (i.e., the objective dimension), individuals' degree of freedom and resources to meet their desires (i.e., the preference satisfaction dimension), individuals' realization of their own potential (i.e., the flourishing dimension), the relative prevalence of positive moods (i.e., the hedonic dimension) and individuals' feeling and assessment of their own lives (e.g., the evaluative dimension) (Atkinson and Mourato, 2015; MacKerron, 2012). Although how to evaluate such aspects appears complex, the path followed by many researchers leads through the examination of the drivers of human development. The most famous composite index, the Human Development Index (HDI), is calculated by incorporating three relevant aspects of individual life: life expectancy, education and access to goods and services (Mericková and Halásková, 2014). Trivially, the index measures how well and for how long residents of a nation can live considering their health, education and incomes. The HDI approach has been extended to the assessment of inequality conditions within countries using the inequality adjusted HDI indicator (UNDP, 2019). Some authors further include sustainability measures in the calculation to also consider environmental sustainability as a dimension of wellbeing (Biggeri and Mauro, 2018; Hickel, 2020), while others add further dimensions such as peace and happiness (Prakash and Garg, 2019). Other indicators of wellbeing have been deeply analysed by Maridal et al. (2018).

The historical roots of the general perspective of the Stiglitz-Sen-Fitoussi Commission date to the aftermath of the great crisis of 2008. Despite the nature of the event, the aftershocks resonated for years, affecting both economic 


\section{INSIGHTS INTO REGIONAL DEVELOPMENT}

ISSN 2669-0195 (online) http://jssidoi.org/jesi/ 2020 Volume 2 Number 4 (December)

http://doi.org/10.9770/IRD.2020.2.4(1)

and non-economic performance. The intuition of the authors is that the crisis and society's response to it determined the loss of accumulated capital. Many experts have emphasized (Fleurbaey and Blanchet, 2013; Stiglitz et al., 2018) the necessity of reinterpreting economic indexes. The national account system based on GDP ignores issues such as income distribution, environmental impact and hidden capital, as well as other forms of knowledge accumulation. Other perspectives have tried to cope with these limitations. An environmental perspective on accounts suggests the addition of natural resource flows to national accounts (Leunig, 2011; Monfreda et al., 2004). In this line of argument, natural capital represents a direct source of welfare for nearby communities; therefore, its protection indirectly influences human users (Kamarianakis and Xepapadeas, 2006). Strong sustainability suggests the need to avoid the use of neoclassical indexes to avoid the errors of policies based on them (Kallis, 2011; van den Bergh, 2011): material consumption drives economic growth, inducing the loss of irrecuperable amounts of permanent capital (van den Bergh, 2011). The commonality between these fields is the link between indexes and policy-making: a change in perspective on the former will impact the latter. The elaboration of new indexes needs to start from the key factors of wellbeing in our society, with aspects and definitions that can be operatively accounted for.

The consumption of both goods and services directly affects standards of living; a society with a high HDI generally should have access to quality healthcare, enough food supplies and broad labour possibilities. The source of such wellbeing could be related to private entrepreneurship as well as public governance. Good governance can improve life quality perceptions either directly or indirectly. The direct effect arises because good governance is preferable to bad governance for improving both social and institutional trust and political consensus, in turn influencing growth and general perceived wellbeing. In the indirect case, good governance can be viewed as a generator of the stream of services, goods and opportunities derived from public governance (Helliwell et al., 2018). Access to services and better job opportunities are directly related to the education system, which is a public service in the EU. Similarly, safe and healthy livelihoods are secured by access to healthcare. Good governance in the provision of such public goods strongly fosters the general level of education and life expectancy (Hardeman and Dijkstra, 2014; Prakash and Garg, 2019).

Citizens' use of and general concern over public goods and services has tended to be similar across Europe in recent decades (Lefebvre et al., 2010). This positive feedback loop has improved the general quality of governance, but over the years, European countries have experienced different compositions of expenditure on pure public goods such as defence, public order and justice and merit goods ${ }^{\dagger \dagger}$ such as health, education and other social services (Fiorito and Kollintzas, 2004). In particular, the returns to investing in knowledge, which could be research, innovation or education, affect the feedback loop of wellbeing growth in the long term (Paliova et al., 2019). Heitger (2002) provides evidence of a general trend of expansionary government spending on public goods, albeit with different patterns among European countries; the author highlights that for OECD countries, public expenditure dedicated to public goods over GDP is on average 14\%. Regardless, there is no evidence of a strict relation between public expenditure on public goods and wellbeing. Davies (2009) highlights that public expenditures and investments are associated with an increasing level of HDI for developed countries, whereas this is not evident for less developed countries. Therefore, the effect of public governance on wellbeing apparently depends on the initial socio-economic conditions of the country itself.

\footnotetext{
$\dagger \dagger$ The distinction between public and merit goods derives from their respective intrinsic natures and modes of delivery. The former can be provided only by a public body to avoid market failures as they are non-rivalrous and non-excludable, whereas merit goods can also be provided in private form through the market, as they are excludable and rivalrous. The main difference from private goods is that merit goods are provided by the public budget as a political decision to avoid their consumption depending only on citizens' individual willingness to pay, as these goods have strong positive externalities on society as a whole (Pulsipher, 1972). In this paper, we refer to public goods in a broad sense, encompassing both pure public and merit goods.
} 


\section{INSIGHTS INTO REGIONAL DEVELOPMENT}

ISSN 2669-0195 (online) http://jssidoi.org/jesi/

2020 Volume 2 Number 4 (December)

http://doi.org/10.9770/IRD.2020.2.4(1)

Europe generally stands at the frontier of HDI, with some peculiarities. For instance, there is great heterogeneity in performance. Within nations such Italy and Spain, we can observe both under- and over performance on certain indicators (Charron et al., 2012). Differences in public goods and governance are evident if evaluated at the national level but not at the regional level. This is especially relevant for indicators related to education and healthcare (Paliova et al., 2019). On the whole, there is no stark difference between the access provided by southern and northern European countries. Education is, on the other hand, the compass of difference, especially in the long term. North-eastern countries display a higher level of education than their southeastern peers. Studies stress the long-term effect that education has on economic performance and wellbeing and governance (Paliova et al., 2019).

The approach applied in other studies focuses on developing indicators to compare nations or regions. Such indexes normalize outcomes in such a way that it is possible to create scores and ranked lists. Furthermore, many authors consider public goods such as peace, environmental safety and others to be main factors in wellness. This approach has the flaw of interpreting wellness or its drivers in a relative manner. It eliminates the possibility of evaluating the drivers by country in absolute terms. We will therefore present here the dynamics of public goods such education and healthcare across the EU by considering public expenditure for selected countries from a longterm perspective using the Eurostat dataset.

\section{Main economic and fiscal dynamics of selected EU countries: an overview}

Before we conduct the analysis of key indicators, one interesting point might be worth mentioning. The budget response to the most recent economic downturn was not uniform within the EU. Some countries (i.e., Italy, France, Spain, Portugal, UK) experienced an expansion of the debt-to-GDP ratio, whereas for others, the opposite occurred (see Fig. 12 in Appendix A). In most cases, 'debt crises' are stagnations of economic productivity (International Monetary Fund, 2017), which may depend on insufficient structural investments in the drivers of growth (education and innovation) (UNIDO, 2018, 2016). This is the iconic depiction of EU fragmentation: a lack of macroeconomic equilibrium within the area and macroeconomic mismanagement of convergence. The divergences are highly related to structural growth discrepancies and the 'expansionary austerity' $\$$ measures adopted in the EU after the crisis. (Conversely, the USA was, at the time of writing, at a $3.7 \%$ unemployment rate, the lowest since the 1960s.)

There is, in fact, a common ascending trend (Fig. 1) in expenditure after the crisis to cope with social issues and a significant decrease starting in 2012-13, after which the EU relied on monetary policy only to address the stagnation. Though they did not increase their budgets, the two pairs of Sweden-Denmark and France-Italy seem to have resisted the common declining trend. Divergences have also generated serious trade imbalances ${ }^{\S}$ (e.g., excessive German and Dutch trade surpluses, well beyond the $+5.9 \%$ EU target ceiling, a signal of uncorrected imbalances in other aggregate demand factors). As mentioned above, both structural economic conditions and different fiscal approaches explain the heterogeneity across countries within the common trends. A first dynamic

\footnotetext{
$\$+$ In this regard, the trend in total expenditures in relation to GDP seems to reflect Krugman's (2018) comment on the 'premature turn to austerity': "In my view we suffered huge, unnecessary losses of output and employment because of the premature turn to austerity. However, the world avoided descending into a full 1930's style depression, which in effect left doctrinaire economists free to continue believing what they wanted to believe". In this regard, expansionary austerity (Alesina and Ardagna, 2012), that is, growth driven by reduced public spending stimulating private investments, seems to have been effective as well, even if full employment is still a distant target for the EU ten years after the crisis. In other words, the EU has not suffered a 1930s-style downturn, but the current recovery is slower than that of the 1930s (Krugman, 2018). Inflation is still lagging at approximately $1 \%$ in spite of very expansionary monetary policy (quantitative easing), which has involved negative interest rates for years. Krugman's conceptual approach is a main line of narrative to read through the data we present here.

$\S \S$ It is worth noting that in a common trade area with both economic and political links, not all countries can run large trade surpluses given fundamentals and economic specialization.
} 
INSIGHTS INTO REGIONAL DEVELOPMENT

ISSN 2669-0195 (online) http://jssidoi.org/jesi/ 2020 Volume 2 Number 4 (December) http://doi.org/10.9770/IRD.2020.2.4(1)

trend is the reduced deficits when growth was present in the 1990s. This was also the period when countries were approaching the creation of the euro area: financial markets reduced the spreads on the EU bonds (the difference in interest rates with German bonds) to almost zero. It is worth noting that some differences in the expenditure ratios were present, without any clear division that could be attributed to economic models, even during the precrisis period of growth. Global economic growth stimulated tax revenues in some countries more than others through GDP and tax structure differences, while public expenditures presented the usual structural differences. In fact, the fiscal composition, fiscal spending level and level of public good investments characterise the varieties of capitalism within capitalist economic systems. Fiscal revenues in the union range from above $46 \%$ (Sweden) to $33 \%$ (UK). Increases over time are witnessed for France and Italy, which have tried, to some extent, to maintain medium-high deficit spending policies. Germany is in between this pair and a heterogeneous club of five other countries (two representatives of the eastern EU, the UK, Spain and Portugal). The normal increase of deficits in the crisis was due to a lack of tax revenues and (in indebted countries especially) a reduction in expenditures. This can also be assessed by looking at the trend for expenditure on public services in general. As Table 1 shows, on this indicator, countries present a rather homogeneous trend that seems not to be affected by the crisis shock in a substantial way. Rather, the table shows a smooth decline in expenditures over time, especially in Germany and Italy but also in Sweden and Denmark, whose welfare systems seem to be radically affected. Countries such as the UK, Czech Republic and Spain, among others, present less clear figures, with erratic downs but also ups over time. France, quite expectedly, presents the top figure, ascending to that position before the crisis years and then remaining stable. All other countries, including Germany and Denmark, have reduced expenditures from 2008-09. After the crisis, fiscal revenues on GDP generally increase across countries to cope with public deficits deriving from stagnating GDP as part of the 'austerity' rationale. However, the post-crisis situation is still quite heterogeneous and a signal of the EU's fiscal weakness: it lacks homogeneous and coordinated fiscal policies, with countries that still pursue strong (expansionary) fiscal austerity in face of higher unemployment levels than the EU average.

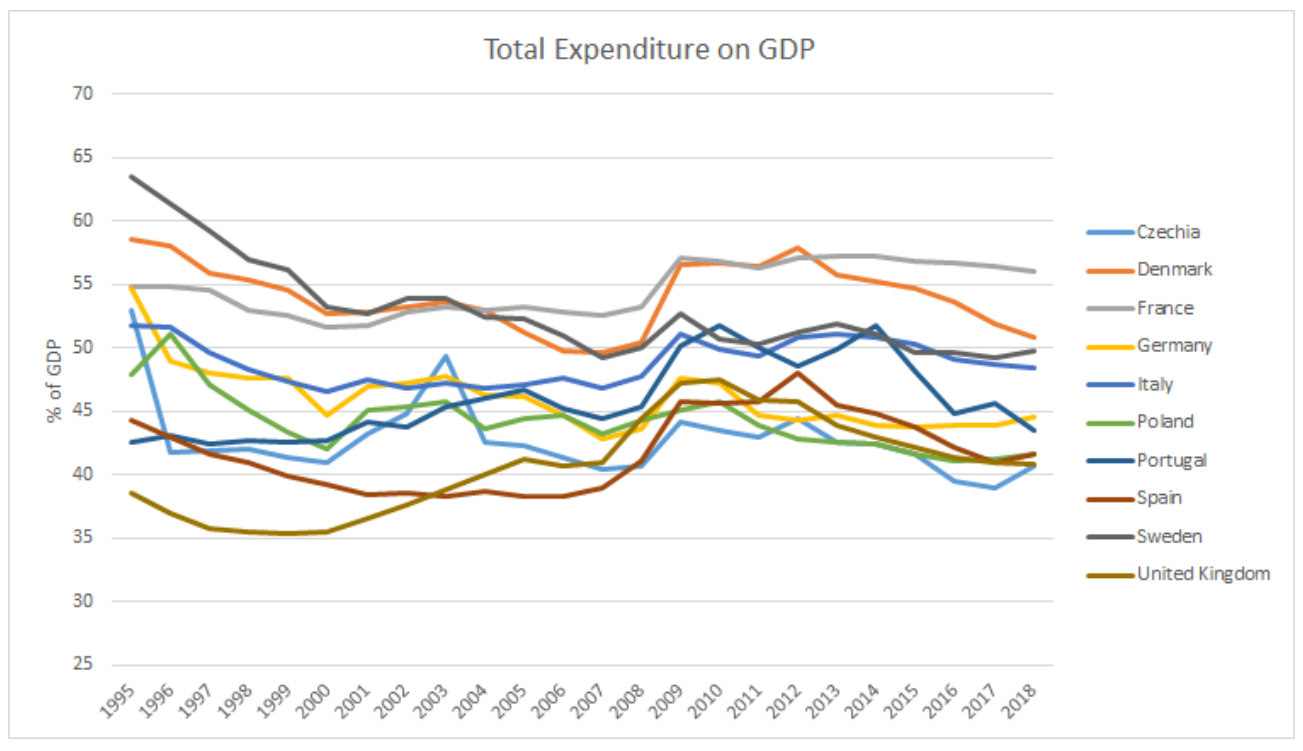

Fig. 1 Total Expenditure as Share of GDP

Source: own elaboration on data from Eurostat 
INSIGHTS INTO REGIONAL DEVELOPMENT

ISSN 2669-0195 (online) http://jssidoi.org/jesi/

2020 Volume 2 Number 4 (December)

http://doi.org/10.9770/IRD.2020.2.4(1)

\section{Health, Education, and Innovation as drivers of wellbeing and growth}

Fiscal policy, in its essence, encompasses economic, legal and institutional aspects of government budgeting with the aim of achieving strategic goals and objectives for the overall welfare of the citizenry. Modern budget strategies try to couple the necessity of responding to negative socio-demographic trends with ensuring fiscal stability and sustainability (Chugunov et al., 2019). In the following three subsections, we present insight into key indicators on substantive items related to wellbeing and growth (health, education and public R\&D expenditures), considering data from 1995 to 2018, with special attention paid to trends during the economic crisis.

\subsection{Health}

The effects of economic shocks such as recessions on the health outcomes and wellbeing of citizens are mixed. The possible loss of employment is likely to generate a higher rate of mental health diseases (e.g., depression, stress, anxiety) and eventually higher rates of suicide, drug addiction and criminal offenses (i.e., homicides) (Buffel et al., 2015). On the other hand, some studies have identified that a higher rate of unemployment is associated with lower rates of traffic injuries, alcohol-related deaths, and hospital admissions in the long term (Gerdtham and Ruhm, 2006; Ruhm, 2006). In essence, health can be considered a form of human capital that does not influence productivity itself but rather the amount of time spent in productive activities (Grossman, 1972). When facing a fiscal crisis, policymakers always struggle over whether to maintain, increase or reduce health expenditures (Cylus et al., 2012). Health disinvestment and reduced wellbeing can result in a negative impact on the economy even in the long run (Quaglio et al., 2013).

In fact, in the aftermath of the most recent economic downturn, health systems appear to have been strongly affected. Many EU countries adopted severe austerity policies with sharp cuts to public expenditure, including both reductions in health budgets and important structural reforms such as hospital closures and mergers and reductions in hospital bed numbers without proper investments in primary care, preventive medicine and health information systems (Quaglio et al., 2013). Contractions in health spending have occurred in various forms within the EU. Greece saw its health expenditure budget cut from $9.8 \%$ of GDP to $6 \%$ after the economic crisis. In that period, even though hospitals faced a reduction in budgets of approximately $40 \%$, there was an increase of $30 \%$ in the utilization of public health services in the country (Ifanti et al., 2013). Other countries (i.e., the UK) froze or cut the wages of healthcare workers while implementing only weak policies for worker replacement (Karanikolos et al., 2013; Quaglio et al., 2013). The 2007 economic downturn was also the motive for structural reforms and the reorganization of hospital infrastructures and primary care interventions. This was the case in Italy, with massive hospital closures and mergers enacted immediately after the economic crisis. The result was a number of beds per 1000 persons below the EU average in 2010 (4.1 in Italy compared to 5.5 in the EU) (Quaglio et al., 2013). However, the economic crisis implied no changes in the scope of healthcare (i.e., the benefit packages provided by states), although the breadth (e.g., coverage of the population) in some countries (e.g., France, Greece, Italy, and Portugal) was decreased through increases in user charges for some health services. Increasing charges in primary or ambulatory specialist care might worsen health outcomes and imply a probable increase in the use of free, resource-intensive services (Karanikolos et al., 2013).

Considering a broader time frame of analysis, from 1995 to 2018, while some countries such as France, Denmark, and the UK spent relatively more, critically low figures emerge for Poland, Greece, Portugal, and Spain. The latter two disinvested in health, reducing one of the pillars of human development; indeed, health is one of the three key indicators in the main HDI indexes of the UNDP (Mazzanti and Gilli, 2018). Spain and Portugal also present critically low figures for education. This disinvestment trend might have stopped the weak convergence that existed within the EU area (Mazzanti and Gilli, 2018) and is a signal of a potentially socio-economically unsustainable path. Reductions in health expenditures might also affect overall healthcare provision (e.g., leave medical needs unmet). Healthcare and prevention budgets have been under intense pressure (Quaglio et al., 2013), putting public health further at risk, as weakening disease prevention can reduce the resilience of the EU health 


\section{INSIGHTS INTO REGIONAL DEVELOPMENT}

ISSN 2669-0195 (online) http://jssidoi.org/jesi/ 2020 Volume 2 Number 4 (December)

http://doi.org/10.9770/IRD.2020.2.4(1)

system as whole to exogenous shocks such as the recent COVID-19 outbreaks. However, the critical effects of a progressive shrinking of health spending might be partly compensated with increasing expenditures on, for instance, social protection and education on the promotion of good health (Karanikolos et al., 2013). For per capita spending in this sector, Fig. 17 (see Appendix B) shows a stable pattern with marked differences among countries. Between the highest trend of Denmark and the lowest of Poland, different healthcare management models can be identified.

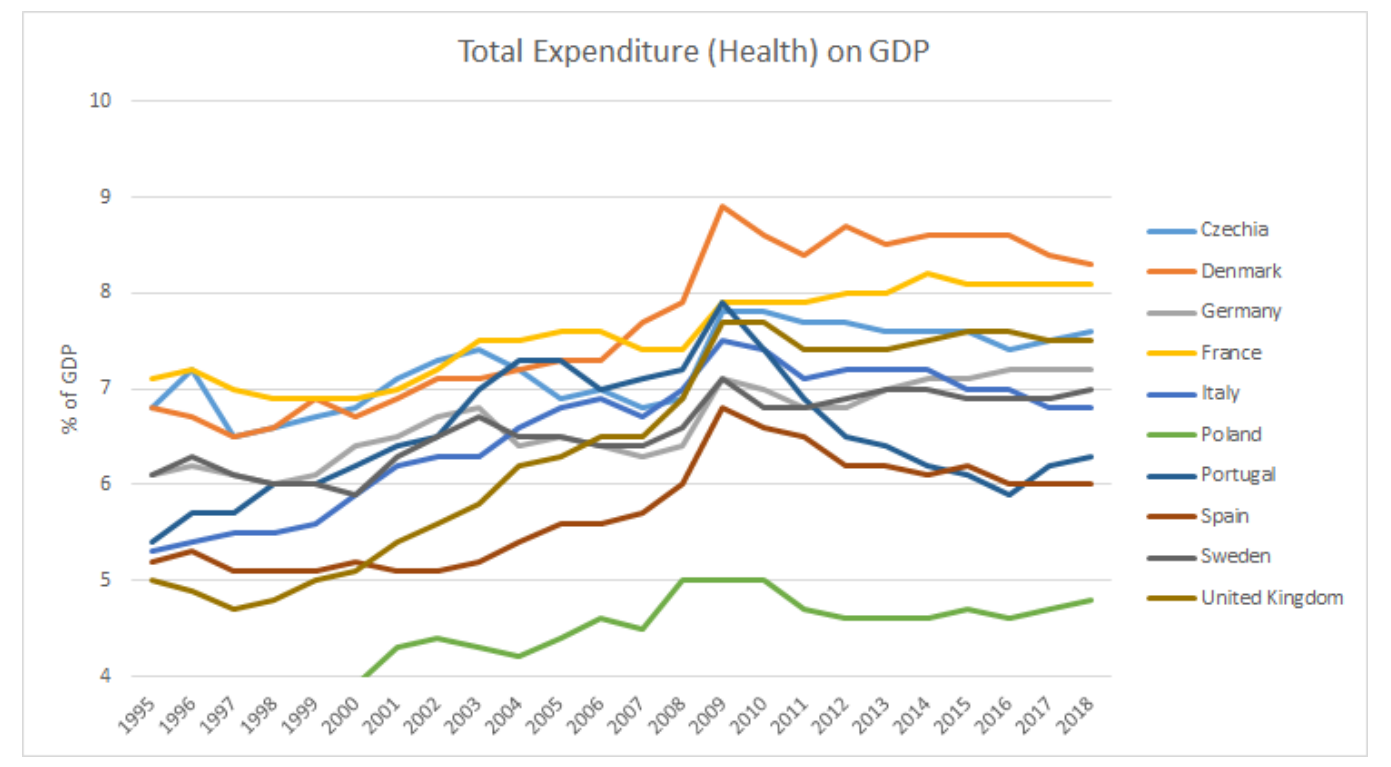

Fig. 2 Total Health Expenditure as Share of GDP

Source: own elaboration on data from Eurostat

\subsection{Education}

Education and health are objectives monitored by prestigious international organizations (e.g., UNESCO, the WHO). Public expenditure in those two areas can also be considered investments in different aspects of human capital (Grossman, 1972; van den Heuvel and Olaroiu, 2017). The right to education is virtually guaranteed by many international conventions, agreements and documents (e.g., the Universal Declaration of Human Rights, the Fourth Geneva Convention Relative to the Protection of Civilian Persons in Time of War). In addition, the nexus connecting education, research and innovation could provide a consistent boost to economic growth, equity and social inclusion. Many surveys identify a higher level of education as associated with higher satisfaction with one's job, place of work, and life (Mărginean, 2014). Investments in this area might be perceived as an attempt by governments to improve the lives of citizens, generating economic, social, and political stability (Tendetnik et al., 2018). Furthermore, there is a significant influence of higher education on employment, albeit with heterogeneous effects among EU countries for historical reasons. In the immediate aftermath of the 2007 crisis, in countries such as Spain and Italy, more educated workers faced less unemployment, whereas in Greece, there was no marked difference (Snieska et al., 2015). The share of education expenditures in the EU is also heterogeneous, ranging between 4 and 7\% of GDP. In 2010, for instance, the highest level of education expenditure was in Denmark (8.4\% of GDP), and the lowest was in Greece and Slovakia, with less than half of the top share (4.1\% of GDP) (Fig. 3). This is, on the one hand, normal, but given that human capital is a key driver of growth and a pillar of HDI, such spending is crucial for EU convergence and overall sustainability. The top investors are Scandinavian countries (Denmark and Sweden), while the lagging ones are southern EU countries (Italy, Spain, and Germany). It is worth noting the appalling decrease in education expenditures after the crisis in the UK and Portugal. Overall, the trend did not change after 2008-2009: higher education investments were not a response to the recession, at 


\section{INSIGHTS INTO REGIONAL DEVELOPMENT}

ISSN 2669-0195 (online) http://jssidoi.org/jesi/ 2020 Volume 2 Number 4 (December) http://doi.org/10.9770/IRD.2020.2.4(1)

least on average. Sweden, Denmark and France present the most positive trends and absolute figures. Again, different economic and institutional systems seem to produce variegated responses to sustainability challenges. On the other hand, the economic crisis also drew a surprising response from higher education institutions across Europe. In Spain and Italy, for instance, the years immediately after 2007 witnessed an increase in the efficiency of higher education institutions (e.g., an increase in the number of graduates and high-quality scientific publications) despite budgetary restrictions (Martínez-Campillo and Fernández Santos, 2019). Per capita trends in education expenditures (Fig. 15 in Appendix B) appear to confirm that Spain and Italy pertain to the cluster with lower spending together with Portugal and the Czech Republic. A second cluster can be identified among the Central European countries (e.g., France, Germany, and the UK), whereas Denmark and Sweden spend the highest amount of funds per inhabitant.

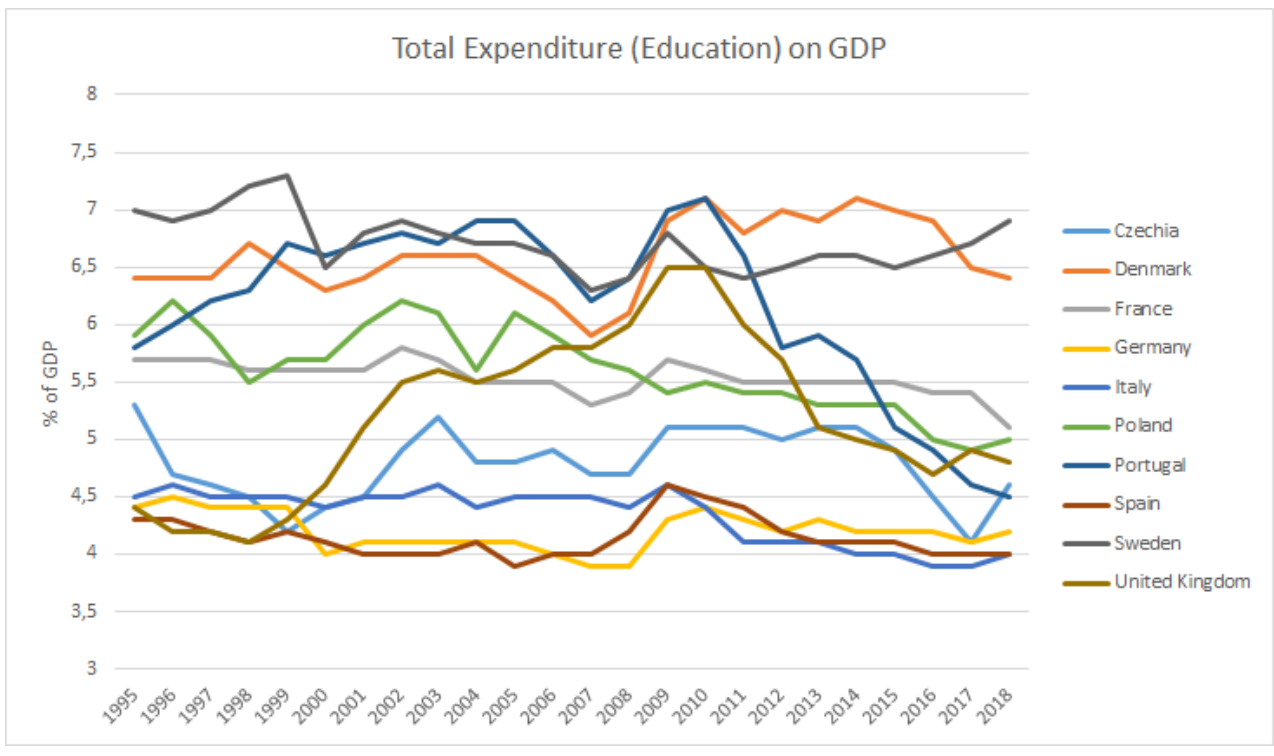

Fig. 3 Total Education Expenditure as Share of GDP

Source: own elaboration on data from Eurostat

\subsection{R\&D}

R\&D is the key driver of invention, innovation and GDP growth in the long run. Public expenditure typically sustains private $R \& D$, treating it as a public good because the positive external effects on society cannot be totally internalized by private investments, leading to under-supply of $R \& D$ and causing market failures and lower benefits for society as a whole (Hud and Hussinger, 2015). However, the effect of public investments in R\&D and the private innovation response of firms is still not clear in the literature (Alonso-Borrego et al., 2014; David et al., 2000). Typically, public investments in $R \& D$ are beneficial for avoiding social welfare losses due to public good problems. However, a so-called crowding-out effect may arise from the incentive of firms to reduce their private investments in $R \& D$ by replacing them with public funds, which in the long term can result in distorting effects on potential growth levels (Hud and Hussinger, 2015).

Private investments in R\&D can react to economic crises in two ways: countercyclically, with boosts to R\&D as a measure to cope with production losses, or procyclically, with reductions to R\&D expenditures because of uncertainty and the declining profitability of new investments (Hud and Hussinger, 2015). Public expenditure on $\mathrm{R} \& \mathrm{D}$ can follow this same pattern, with government budgets dedicated to innovation either increasing or shrinking depending on government expectations of return on innovation investments. In fact, sustainable governmental R\&D spending in periods of crisis can help countries recover from financial downturns, leading to 
INSIGHTS INTO REGIONAL DEVELOPMENT

ISSN 2669-0195 (online) http://jssidoi.org/jesi/ 2020 Volume 2 Number 4 (December)

http://doi.org/10.9770/IRD.2020.2.4(1)

economic growth through innovation (Hud and Hussinger, 2015). Empirical results show heterogeneous figures for public intervention in R\&D investment during the last economic crisis (Filippetti and Archibugi, 2011; Makkonen, 2013).

The global economic downturn and credit crisis that affected European countries after 2008 reduced investments in $R \& D$ because of the credit crunch caused by general bank disinvestment in risky activities (Archibugi, 2017). R\&D was also reduced because of both the general demand contraction and companies' unresponsiveness to public R\&D incentives due to the high level of uncertainty after the crisis (Hud and Hussinger, 2015). However, this did not occur in all countries and in all sectors; in fact, in northern areas such as Finland, Switzerland, Germany and Sweden, a relevant number of companies conserved their level of investment in R\&D and, in some cases, increased it because of sectoral specializations in which R\&D is a key element of competitiveness (Brem et al., 2020). These firms investing more in R\&D are characterized as young, flexible and small and looking for new market opportunities (Archibugi et al., 2013). Compared to older and larger companies, they invested more in R\&D despite the economic crisis (Archibugi, 2017).

Beyond the economic downturn, heterogeneous structural patterns in R\&D investment among EU countries are evident from our analysis (Fig. 4). During the last three decades, national investments in R\&D present striking and consolidated differences. Against the Lisbon agenda target of 3\% of GDP for R\&D investment, only Sweden has historically invested more than the threshold. Denmark and Germany follow with somewhat increasing patterns. This northern EU attitude towards R\&D investments, which is explained by both public policy actions and an economic structure with a high density of medium-large firms, is not replicated in other EU countries. Key countries such France, the UK and Italy lag substantially behind. Italy's R\&D investment has flatlined, serving as a clear indicator of Italian stagnation in productivity and GDP over the last 15 years. Other southern EU countries also lag behind. This gap might also explain the EU divide regarding environmental productivity (e.g., CO2/GDP patterns, Mazzanti and Musolesi, 2014). Eastern EU countries also lag, with R\&D spending at approximately 1$1.5 \%$ of GDP, although the Czech Republic shows some positive reaction after the crisis. For education investments, it does not seem that the EU overall adopted a strong innovation-oriented strategy to deal with the crisis and post-crisis objectives, namely, stabilizing full employment, achieving the 2020 environmental and energy targets and building the pillars for long-run growth. That said, R\&D spending, the main driver of long-run economic productivity, has increased overall. It is worth noting that the four large EU economies, Italy, France, Germany, and the UK, display positive but moderate increases over the last 15 years. Sweden moderately increased R\&D spending but started from a level of higher than 3\% of GDP. Eastern EU countries (Poland, Czech Republic) and Spain and Portugal show greater increases than the abovementioned countries, but the initial levels were very low. Overall, it seems that the increases are (i) heterogeneous, though coherent with the initial levels, and (ii) insufficient on average and especially for the leading economies. 


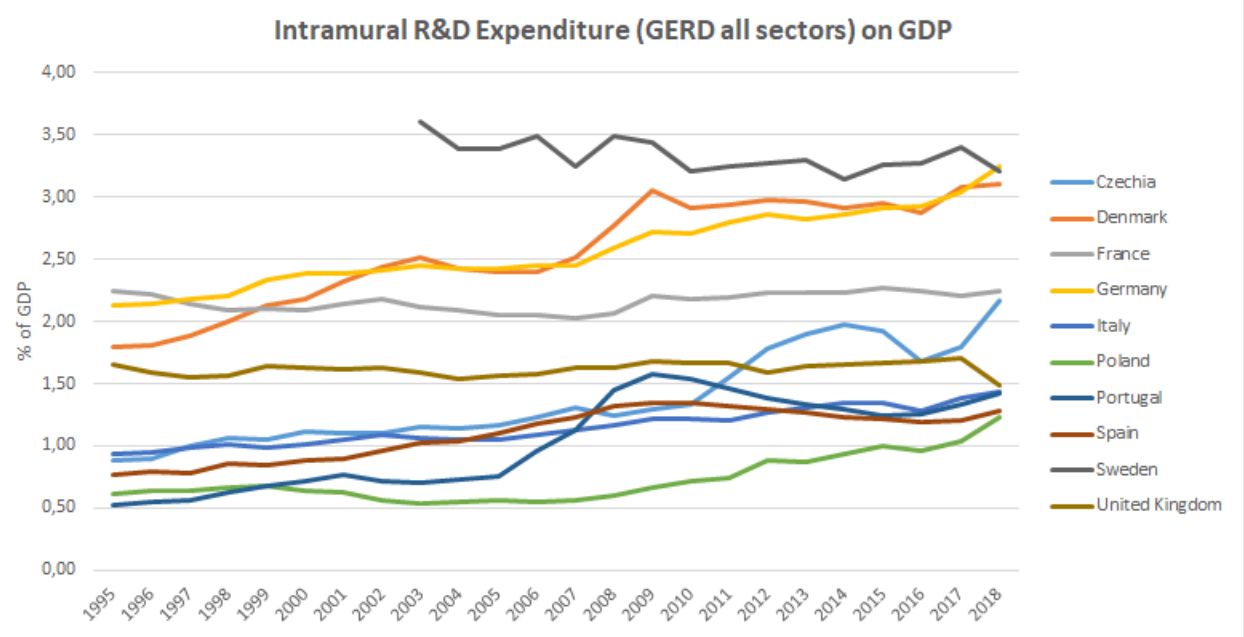

Fig. 4 Intramural Government R\&D Expenditure (GERD) for All Sectors as Share of GDP Source: own elaboration on data from Eurostat

\section{Country-by-country analysis (a look at the 2000-2016 transition)}

Historical trends can also be analysed by looking at indexes that provide a different angle, namely, the variation, independent of GDP, of the various items. The evidence below complements the previous analyses in providing a rich picture of EU variation and criticalities. Table 1 summarizes the main trends by country and indicator (graphs are available in the Appendix A) since 2000, a period that includes the economic downturn in the middle. Regarding debt and growth patterns, strictly integrated analyses should always consider the dynamics of growth drivers: namely, fiscal measures (deficits) in the short run and innovation and education, that is, knowledge, in the long run.

Table 1. Indexes of selected macroeconomic and fiscal indicators. 2016 index level per capita (2000=100)

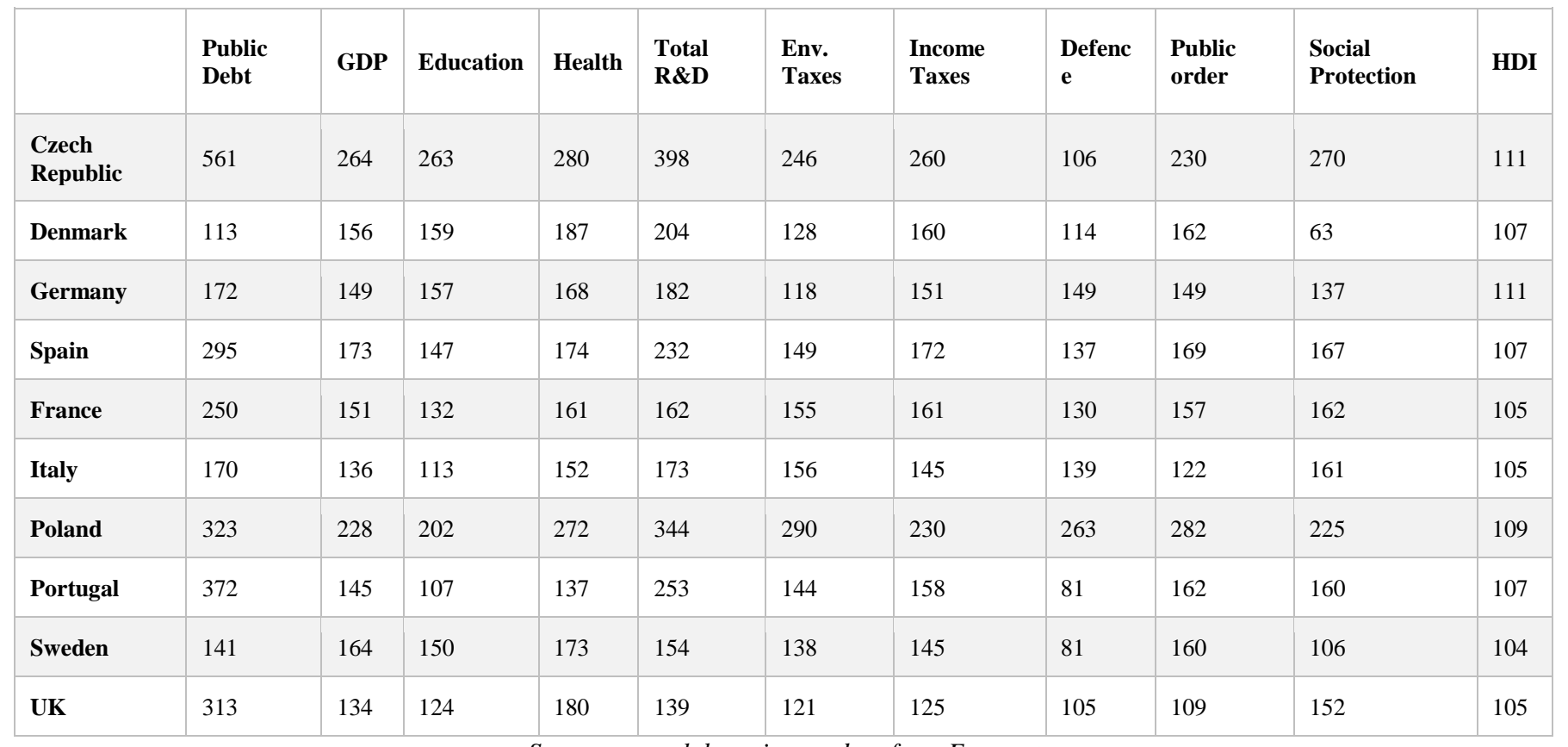

Source: own elaboration on data from Eurostat 


\section{INSIGHTS INTO REGIONAL DEVELOPMENT}

ISSN 2669-0195 (online) http://jssidoi.org/jesi/

2020 Volume 2 Number 4 (December)

http://doi.org/10.9770/IRD.2020.2.4(1)

The trends show high debt growth in the eastern EU (highest in the Czech Republic), the UK and the southern EU. For the eastern EU, debt growth is partially offset by high GDP growth, which is nevertheless insufficient to compensate for the debt increases. Poland and Czech Republic double their spending in almost all the public sectors analysed, but they also display growth in public debt by threefold and fivefold, with respect to 2000 (see Table 1). On the other hand, these two member states do manage to keep the debt-to-GDP ratio lower than the threshold established by the Growth and Stability Pact (GSP). France and Italy present lower debt growth but also low economic growth. Only Denmark and Sweden present GDP growing at a faster pace than nominal debt.

Expenditures in social protection as a share of GDP show that countries with consolidated state intervention, such as France and Sweden, occupy the two top positions. In the low-ranked positions, we find two eastern EU countries, namely, Poland and the Czech Republic; the UK, with its Anglo-Saxon variety of capitalism; and Portugal and Spain, two southern EU economies that have suffered from the sovereign debt crisis. Overall, the share and the dynamics are heterogeneous. Three main comments emerge: (i) Country differences seem to have more of a structural nature. (ii) The response to the crisis is a strong reduction in spending in some countries. (iii) A decrease in most countries appears starting in 2013 due to austerity rationales. In the last 16 years, spending on social protection has increased for the whole EU, with the highest rates for Poland, the Czech Republic, Portugal, and Spain. As already mentioned, in some cases, social protection spending might prevent the deterioration of the social and economic condition of some categories of the population more exposed to certain diseases (e.g., elderly people, homeless people, children) by, for instance, alleviating financial hardship, undernutrition and hazardous alcohol drinking (Reeves et al., 2014).

Environmental taxes increase over the period. It appears joining the European Union was a substantial motive for eastern European countries, that were lagging at the beginning of the period, to increase green taxes. Among the four large economies, only Italy and France show taxes increases greater than their GDP increases. The Nordic countries that introduced environmental taxes in the 1990s show slower taxation dynamics. Revenue flows present a mixed, slightly downward trend. Countries with high taxation and structured welfare systems (e.g., France, Germany, Sweden) rank in the lowest positions. Italy, Poland, Denmark are a mixed club that display high revenue shares that are nevertheless decreasing for Denmark but increasing for Italy; these countries are among those that have used environmental and energy taxation as a channel to cope with the post-crisis fiscal vulnerabilities (in relation to deficit debt more than public good financing). Environmental taxation is still below its potential levels. It has increased in some cases but mainly for mere fiscal reasons. Even though the share of such taxation remains low compared to overall tax revenues, the proportion, externality links and earmarking of such taxes could be extended to achieve double dividends in economic and environmental terms.

Eastern EU countries also show the highest increases regarding income taxes: fiscal consolidation, GDP growth and entrance into the EU are the main drivers. All other EU countries, except for the UK, show homogeneous increases in income taxes, albeit at a slower pace. The weak increase in the UK is possibly one reason for the high deficit and debt increases in comparative terms. Social contributions follow similar patterns. While countries (eastern EU) that have set up new welfare systems show strong increases in this indicator, countries that already had a structured welfare system in 2000 show only slight increases or even, interestingly, a reduction in the amount of social contributions (Denmark).

It is also interesting to mention that, even though some member states have almost doubled their spending in the last 16 years, this increase has not been matched by an increase in the HDI. The index is composed of several dimensions, encompassing the economic and social spheres, health and education. In this sense, the composition of the indicator might cover the relative performance of states in each dimension. Of further note is the heterogeneous scoring not only between states but also between regions within the EU. Especially for eastern European countries, capital city regions tend to outperform the others overall (Hardeman and Dijkstra, 2014). Regardless, some EU countries have been able to increase HDI at a higher rate than others, providing even in this case a scattered distribution of countries that can be divided into different clusters: those that have improved 


\section{INSIGHTS INTO REGIONAL DEVELOPMENT}

ISSN 2669-0195 (online) http://jssidoi.org/jesi/

2020 Volume 2 Number 4 (December)

http://doi.org/10.9770/IRD.2020.2.4(1)

general wellbeing conditions (namely, Denmark, Germany, Czechia, Poland, Portugal and Spain) by between 7\% and $11 \%$ and those that have increased HDI relatively less, by approximately 5\% (namely, the UK, Sweden, France and Italy).

\section{Conclusions}

Structural heterogeneity in the examined dynamics and across countries was high over the last decades, as was the heterogeneity in the (fiscal and investment) responses to the 2009 economic downturn. While, on the one hand, some heterogeneity is 'normal', an excess might lead to socio-economic imbalances and unsustainable patterns (Gilli and Mazzanti, 2018). For instance, heterogeneity in R\&D and education are insufficient to cope with postcrisis stagnation and long-run growth and sustainability necessities. In addition to the historical lack of R\&D funding with respect to the Lisbon agenda targets, critical trends appear for education investments, especially after the economic downturn. Funding for education is staggeringly low, especially in some eastern EU countries (Poland and the Czech Republic), the $\mathrm{UK}^{* * *}$ and Portugal and Spain. Various economic systems show investment deficits in the engines of growth, undermining future convergence of the EU and total wellbeing.

The EU activated relatively small recovery packages just after the 2009 crisis and started reducing growth stimulus after 2013, leaving monetary policy alone to address growth issues. This mismanagement of macroeconomic policy has largely driven EU performance. Investments in R\&D and education are extremely heterogeneous across countries, a signal of low social resilience and fragility. The investments are insufficient to cope with crisis shocks and long-run growth and sustainability necessities. Education and health disinvestments present figures that may undermine cohesion: overall, the trend is not increasing after the crisis. Some countries stabilized their expenditure, while others witnessed drastic reductions (Poland, Spain, Portugal). Education and health trends currently pose serious questions on the overall human development of the EU and its convergence (north-south; east-west). Italy, Poland, Spain, Portugal, and Greece present a substantial reduction of health and education expenditures as a share of GDP over 2010-2018, in face of the well-known stagnation in overall R\&D spending.

Our analysis on per capita trends highlighted structural differences within the EU countries in providing public goods to their citizens. Indeed, a consistent group of these representative countries has not reached $2000 €$ per inhabitant in health spending, $1000 €$ in education spending, or $400 €$ in R\&D spending.

Some EU economies (France, Sweden, Denmark, Germany, the UK, and Italy in some cases) show robust and not decreasing investments. Given the economic performance of the EU ten years after the 2009 crisis, those efforts are probably insufficient to achieve the overall sustainability of the EU. Due to an unsuccessful 'expansionary austerity' rationale, EU economic indicators ten years after the crisis are gloomy: GDP is growing at 1.7\% (Germany at $1.9 \%$ and France at $1.5 \%$ ), and unemployment is at $8.1 \%$ (the respective figures for the USA are 3\% and $3.7 \%$, with similar inflation rates ${ }^{\dagger \dagger}$ ). Furthermore, the structural heterogeneity in the dynamics and across countries was high over the last decades, as was the heterogeneity in (fiscal and investment) responses to the economic downturn and post-crisis objectives (full employment, GDP growth, environmental targets such as '2020-20' and long-run low-carbon transitions). The robustness of wellbeing (HDI) to socio-economic shocks and environmental policies should be investigated. Further studies could shed more light on the convergence/divergence of the different indicators and ultimate wellbeing and sustainability goals.

The objective when the peak of the pandemic has passed will be to structure 'exit' strategies that consider both health and socio-economic aspects. To transition to the post-crisis period, policies and investments should be

\footnotetext{
*** This figure might be one factor behind Piketty's evidence on the 'divide' between Anglo-Saxon models and the models of countries like Sweden, Germany, and Japan with respect to income inequality trends.

tit Source: The Economist, November 10th.
} 
INSIGHTS INTO REGIONAL DEVELOPMENT

ISSN 2669-0195 (online) http://jssidoi.org/jesi/ 2020 Volume 2 Number 4 (December)

http://doi.org/10.9770/IRD.2020.2.4(1)

guided by cultural and theoretical approaches to sustainability and wellbeing. These investments would make our human societies and economic systems even more resilient and prepared to face future shocks, whether economic or health-related or otherwise. Without a mitigation of the inequalities between territories and citizens, there can be neither stable economic growth nor a 'consensus' for the radical ecological transition. The ecological transition and sustainability depend greatly on the technè: new technologies and forms of social organization. It will not be achieved without a broad social consensus, which passes through a better distribution of income and opportunities, and these depend primarily on investments in health and public schooling. As Alexander Langer argued, the present situation attests no ecological transition is possible if it is not socially understood, accepted and shared. The present moment is useful for questioning ourselves again on this point.

The question that arises is as follows: within the fiscal policy response aimed at minimizing socio-economic costs, will a Green New Deal take on a more central role, or will it become a residual part? The importance of a broad fiscal response is important for the effects on 2020-21 GDP: whether we put a Green New Deal at the centre of the response is a political decision that can have medium- to long-term impacts. One choice is to extend the Green New Deal and the just transition by formulating a broad Wellbeing New Deal, with a focus on the environment, schooling, healthcare, or human development. The policy suggestion is not a panacea, but it derives from knowledge of macroeconomics and sustainability and observations of macroeconomic trends in recent decades.

Drivers of growth and development ( $R \& D$, education, and health expenditures) should be increased in real terms and as a percentage of GDP. Beyond the Lisbon agenda targets, the EU could set a 'South Korea'-style target of $4 \%$ of GDP for R\&D investment. This amounts to an additional $300 €$ billion per year. Education and health expenditure trends should be reversed and increased in most countries, especially in southern Europe + t+ Economic growth should be achieved through more decent and necessary income distribution and capability creation to reduce economic and social fragility, which opens the way to new recessions and a lack of resilience during crises. General fiscal and monetary policies should lead the way by being very expansionary over 2020-21 and more expansionary than in the past, even in a - we hope - post-crisis recovery framework, at least until unemployment figures are as low as $3-4 \%$ and wellbeing indicators are enhanced. Inflation should be monitored, but it does not seem to be a real threat. In fact, deflation is also a possibility, if policies are not expansionary enough.

One concrete point, emerged from this study, is that European strategies on the key human development pillars were heterogeneous during the last decades. The post-2009 recession was characterized by non-expansionary measures that have undermined development in most countries. Due to the lack of a robust investment patterns towards human and sustainable development, European countries were not fully prepared to tackle the COVID-19 shock. An unsustainable response to a crisis generated socio-economic and system fragility. The socio-economic and health costs could have been lower if larger investments, especially in health, innovation and education, had been carried out in between 2010-2019, a sort of 'lost decade'. Europe is now attempting to react with proper fiscal measures and investments in face of the COVID-19 effects. It is worth noting that the pre-virus macroeconomic and development figures should have pointed to the need of a robust pattern of investments. Growth and development figures were already gloomy in 2019 and the years before. The hope is that this lesson is useful to create a solid society and economic system for possible future crises. Let's transform the hope in reality.

\footnotetext{
We note that environmental taxation revenue is still below its potential levels. It has increased in some cases but mainly for mere fiscal reasons. Even though the share of such taxation remains logically low compared to overall tax revenues, the proportion, externality-links and earmarking of such taxes could be extended to achieve double dividends in both the economic and environmental spheres. In addition to environmental taxes, substantial revenues are and will be generated by the auction of emission trading allowances. The total revenues generated by member states from the auctions between 2012 and 30 June 2018 exceeded $€ 26$ billion (in 2017 alone, the generated total revenues were $€ 5.6$ billion), with Italy accounting for around $€ 2$ billion (European Commission, 2018).
} 
INSIGHTS INTO REGIONAL DEVELOPMENT

ISSN 2669-0195 (online) http://jssidoi.org/jesi/

2020 Volume 2 Number 4 (December)

http://doi.org/10.9770/IRD.2020.2.4(1)

\section{References}

Alesina, A., Ardagna, S., 2012. The design of fiscal adjustments (No. w18423). National Bureau of Economic Research, Cambridge, MA. https://doi.org/10.3386/w18423

Alonso-Borrego, C., Galan, J., Forcadell, F., Zúñiga-Vicente, J., 2014. Assessing the effect of public subsidies on firm R\&D investment: A survey. J. Econ. Surv. 28, 36-67. https://doi.org/10.1111/j.1467-6419.2012.00738.x

Archibugi, D., 2017. Blade Runner economics: Will innovation lead the economic recovery? Res. Policy 46, 535-543. https://doi.org/10.1016/j.respol.2016.01.021

Archibugi, D., Filippetti, A., Frenz, M., 2013. The impact of the economic crisis on innovation: Evidence from Europe. Technol. Forecast. Soc. Change 80, 1247-1260. https://doi.org/10.1016/j.techfore.2013.05.005

Atkinson, G., Mourato, S., 2015. Cost-Benefit Analysis and the Environment (OECD Environment Working Papers No. 97), OECD Environment Working Papers. https://doi.org/10.1787/5jrp6w76tstg-en

Biggeri, M., Mauro, V., 2018. Towards a more 'Sustainable' Human Development Index: Integrating the environment and freedom. Ecol. Indic. 91, 220-231. https://doi.org/10/gd86tr

Brem, A., Nylund, P., Viardot, E., 2020. The impact of the 2008 financial crisis on innovation: A dominant design perspective. J. Bus. Res. 110, 360-369. https://doi.org/10.1016/j.jbusres.2020.01.048

Buffel, V., Van de Velde, S., Bracke, P., 2015. The mental health consequences of the economic crisis in Europe among the employed, the unemployed, and the non-employed. Soc. Sci. Res. 54, 263-288. https://doi.org/10.1016/j.ssresearch.2015.08.003

Charron, N., Lapuente, V., Dykstra, L., 2012. Regional Governance Matters: A Study on Regional Variation in Quality of Government within the EU. Eur. Comm. - Reg. Stud. 23.

Chugunov, I., Makohon, V., Krykun, T., 2019. Budget strategy in the conditions of economic globalization. Probl. Perspect. Manag. 17, 101-110. https://doi.org/10/ggqnz8

Cylus, J., Mladovsky, P., McKee, M., 2012. Is There a Statistical Relationship between Economic Crises and Changes in Government Health Expenditure Growth? An Analysis of Twenty-Four European Countries. Health Serv. Res. 47, 2204-2224. https://doi.org/10/ggqnz5 David, P.A., Hall, B.H., Toole, A.A., 2000. Is public R \& D a complement or substitute for private R \& D? A review of the econometric evidence 33.

Davies, A., 2009. Human development and the optimal size of government. J. Socio-Econ. 38, 326-330. https://doi.org/10.1016/j.socec.2008.07.015

Filippetti, A., Archibugi, D., 2011. Innovation in times of crisis: National Systems of Innovation, structure, and demand. Res. Policy 40, 179-192. https://doi.org/10.1016/j.respol.2010.09.001

Fiorito, R., Kollintzas, T., 2004. Public goods, merit goods, and the relation between private and government consumption, European Economic Review. https://doi.org/10.1016/j.euroecorev.2004.01.004

Fleurbaey, M., Blanchet, D., 2013. Beyond GDP: Measuring welfare and assessing sustainability. Oxford University Press.

Gerdtham, U.-G., Ruhm, C.J., 2006. Deaths rise in good economic times: Evidence from the OECD. Econ. Hum. Biol. 4, $298-316$. https://doi.org/10/bnd8mn

Grossman, M., 1972. On the Concept of Health Capital and the Demand for Health. J. Polit. Econ. 80, $223-255$.

Haavard Maridal, J., Palich, L., Morgan, G., Gardner, S., McKinney, J., Bolbocean, C., 2018. Wellbeing Indices: A Comprehensive Inventory of Standards and a Review of Current Comparative Measures. Ecol. Econ. 149, 1-11. https://doi.org/10/gfztvf

Hamilton, K., Hartwick, J.M., 2005. Investing exhaustible resource rents and the path of consumption. Can. J. Econ. Can. Déconomique 38, 615-621. https://doi.org/10.1111/j.0008-4085.2005.00295.x

Hardeman, S., Dijkstra, L., 2014. The EU Regional Human Development Index.

Heitger, B., 2002. The Scope of Government and its Impact on Economic Growth in OECD Countries. Econ. Internazionale Int. Econ. 55, 323-350.

Helliwell, J.F., Huang, H., Grover, S., Wang, S., 2018. Empirical linkages between good governance and national well-being. J. Comp. Econ. 46, 1332-1346. https://doi.org/10/ggqpc8

Heyes, A., 2000. A proposal for the greening of textbook macro:'IS-LM-EE'. Department of Economics, Royal Holloway University of London.

Hickel, J., 2020. The sustainable development index: Measuring the ecological efficiency of human development in the anthropocene. Ecol. Econ. 167, 106331. https://doi.org/10/ggdtt3

Hud, M., Hussinger, K., 2015. The impact of R\&D subsidies during the crisis. Res. Policy 44, 1844-1855. https://doi.org/10.1016/j.respol.2015.06.003 


\section{INSIGHTS INTO REGIONAL DEVELOPMENT}

ISSN 2669-0195 (online) http://jssidoi.org/jesi/ 2020 Volume 2 Number 4 (December) http://doi.org/10.9770/IRD.2020.2.4(1)

Ifanti, A.A., Argyriou, A.A., Kalofonou, F.H., Kalofonos, H.P., 2013. Financial crisis and austerity measures in Greece: Their impact on health promotion policies and public health care. Health Policy 113, 8-12. https://doi.org/10/f2xsx7

International Monetary Fund, 2017. IMF Fiscal Monitor: Tackling Inequality, World economic and financial surveys.

Kallis, G., 2011. In defence of degrowth. Ecol. Econ. 70, 873-880. https://doi.org/10.1016/j.ecolecon.2010.12.007

Kamarianakis, Y., Xepapadeas, A., 2006. An irreversible investment model with a stochastic production capacity and fixed plus proportional adjustment costs.

Karanikolos, M., Mladovsky, P., Cylus, J., Thomson, S., Basu, S., Stuckler, D., Mackenbach, J.P., McKee, M., 2013. Financial crisis, austerity, and health in Europe. The Lancet 381, 1323-1331. https://doi.org/10/k4c

Krugman, P., 2018. Good enough for government work? Macroeconomics since the crisis. Oxf. Rev. Econ. Policy 34, 156-168. https://doi.org/10.1093/oxrep/grx052

Lefebvre, M., Coelli, T., Pestieauz, P., 2010. On the convergence of social protection performance in the European Union. CESifo Econ. Stud. 56, 300-322. https://doi.org/10.1093/cesifo/ifp030

Leunig, T., 2011. Measuring economic performance and social progress. Eur. Rev. Econ. Hist. 15, 357-363. https://doi.org/10.1017/S1361491611000086

MacKerron, G., 2012. Happiness Economics from 35000 Feet. J. Econ. Surv. 26, 705-735. https://doi.org/10.1111/j.14676419.2010.00672.x

Makkonen, T., 2013. Government science and technology budgets in times of crisis. Res. Policy 42, 817-822. https://doi.org/10.1016/j.respol.2012.10.002

Mărginean, I., 2014. Public Expenditure with Education and Healthcare in EU Countries. Procedia Econ. Finance, 1st International Conference "Economic Scientific Research - Theoretical, Empirical and Practical Approaches", ESPERA 2013 8, $429-435$. https://doi.org/10/ggqnz4

Mazzanti, M., Gilli, M., 2018. Contextualising sustainability, in: Cultures of Sustainability and Wellbeing. ROUTLEDGE in association with GSE Research, pp. 111-134.

Mericková, B.M., Halásková, R., 2014. Income Redistribution and Socio-economic Development. Rev. Econ. Perspect. 14.

Monfreda, C., Wackernagel, M., Deumling, D., 2004. Establishing National Natural Capital Accounts Based on Detailed Ecological Footprint and Biological Capacity Assessments. Land Use Policy 21, 231-246. https://doi.org/10.1016/j.landusepol.2003.10.009

Musolesi, A., Mazzanti, M., 2014. Nonlinearity, heterogeneity and unobserved effects in the carbon dioxide emissions-economic development relation for advanced countries. Stud. Nonlinear Dyn. Econom. 18.

Neumayer, E., 2014. Weak versus Strong Sustainability: Exploring the Limits of Two Opposing Paradigms, Fourth Revised Edition. ed. Edward Elgar Publishing, Cheltenham and Northampton.

Paliova, I., McNown, R., Nülle, G., 2019. Multiple Dimensions of Human Development Index and Public Social Spending for Sustainable Development. IMF Work. Pap. 19. https://doi.org/10.5089/9781513511924.001

Prakash, R., Garg, P., 2019. Comparative assessment of HDI with Composite Development Index (CDI). Insights Reg. Dev. 1, 58-76. https://doi.org/10.9770/ird.2019.1.1(5)

Pulsipher, A.G., 1972. The Properties and Relevancy of Merit Goods 22.

Quaglio, G., Karapiperis, T., Van Woensel, L., Arnold, E., McDaid, D., 2013. Austerity and health in Europe. Health Policy 113, 13-19. https://doi.org/10/f2xsxj

Reeves, A., Basu, S., McKee, M., Stuckler, D., Sandgren, A., Semenza, J., 2014. Social protection and tuberculosis control in 21 European countries, 1995-2012: a cross-national statistical modelling analysis. Lancet Infect. Dis. 14, 1105-1112. https://doi.org/10.1016/S14733099(14)70927-2

Ruhm, C., 2006. A Healthy Economy Can Break Your Heart. Natl. Bur. Econ. Res. 44, 829-848. https://doi.org/10.3386/w12102

Snieska, V., Valodkiene, G., Daunoriene, A., Draksaite, A., 2015. Education and Unemployment in European Union Economic Cycles. Procedia - Soc. Behav. Sci. 213, 211-216. https://doi.org/10.1016/j.sbspro.2015.11.428

Spinozzi, P., Mazzanti, M., 2018. Routing Sustainable Development towards a culture of wellbeing, in: Culture of Sustainability: Theories, Policies, Histories. Routledge, London.

Stiglitz, J.E., Fitoussi, J.-P., Durand, M., 2018. Beyond GDP. https://doi.org/10.1787/9789264307292-en

Tendetnik, P., Clayton, G., Cathcart, K., 2018. Education and nation-state fragility: Evidence from panel data analysis. Int. J. Educ. Dev. 62, 17-26. https://doi.org/10/ggqnz7

UNDP, 2019. Human Development Report 2019- Beyond income, beyond averages, beyond today: Inequalities in human development in the 21 st century.

UNIDO, 2018. Industrial Development Report 2018. Demand for Manufacturing: Driving Inclusive and Sustainable Industrial Development (No. ID/448). United Nations Industrial Development Organization, Vienna.

UNIDO, 2016. Industrial Development Report 2016. The Role of Technology and Innovation in Inclusive and Sustainable Industrial Development. United Nations Industrial Development Organization, Vienna.

van den Bergh, J., 2011. Environment versus growth - A criticism of "degrowth" and a plea for "a-growth.” Ecol. Econ. 70, 881-890.

van den Heuvel, W.J.A., Olaroiu, M., 2017. How Important Are Health Care Expenditures for Life Expectancy? A Comparative, European Analysis. J. Am. Med. Dir. Assoc. 18, 276.e9-276.e12. https://doi.org/10.1016/j.jamda.2016.11.027 
INSIGHTS INTO REGIONAL DEVELOPMENT

ISSN 2669-0195 (online) http://jssidoi.org/jesi/

2020 Volume 2 Number 4 (December)

http://doi.org/10.9770/IRD.2020.2.4(1)

\section{Appendix}

\section{A. Synthesis of other Macroeconomic variables.}

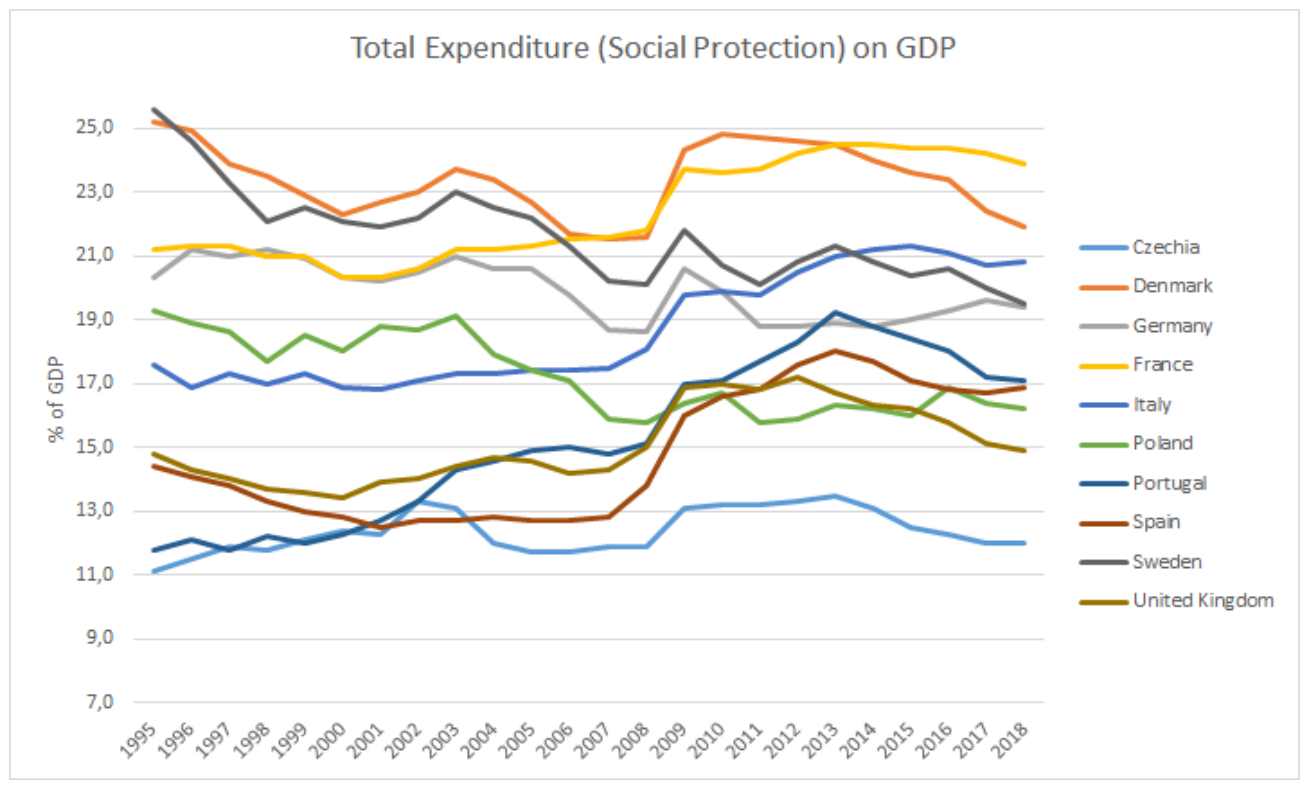

Fig. 8 Social Protection expenditure as Share of GDP

Source: own elaboration on data from Eurostat

Other voices of expenditures account for defence, public order, social protection and finally general services. Last one refers to all expenditures counted outside the cited: for instance, bureaucracy maintenance and inflation adaptation of wages, gross capital formation etc. Starting from social protection (Fig. 8), we could divide the reported countries in three main clusters: who increased, reduced or kept constant such expenditure. This division is similar for all other expenditures. In this case, the shock of 2009 is evident, but the trend is not reversed. For instance, share of GDP devoted to social protection in Sweden, Denmark, Poland and Germany reduced over time. This information must be matched with their economic performances, generally above average in EU28 for the considered period. Southern countries expanded this sector as a measure of balance to the economic crisis. 
INSIGHTS INTO REGIONAL DEVELOPMENT

ISSN 2669-0195 (online) http://jssidoi.org/jesi/ 2020 Volume 2 Number 4 (December)

http://doi.org/10.9770/IRD.2020.2.4(1)

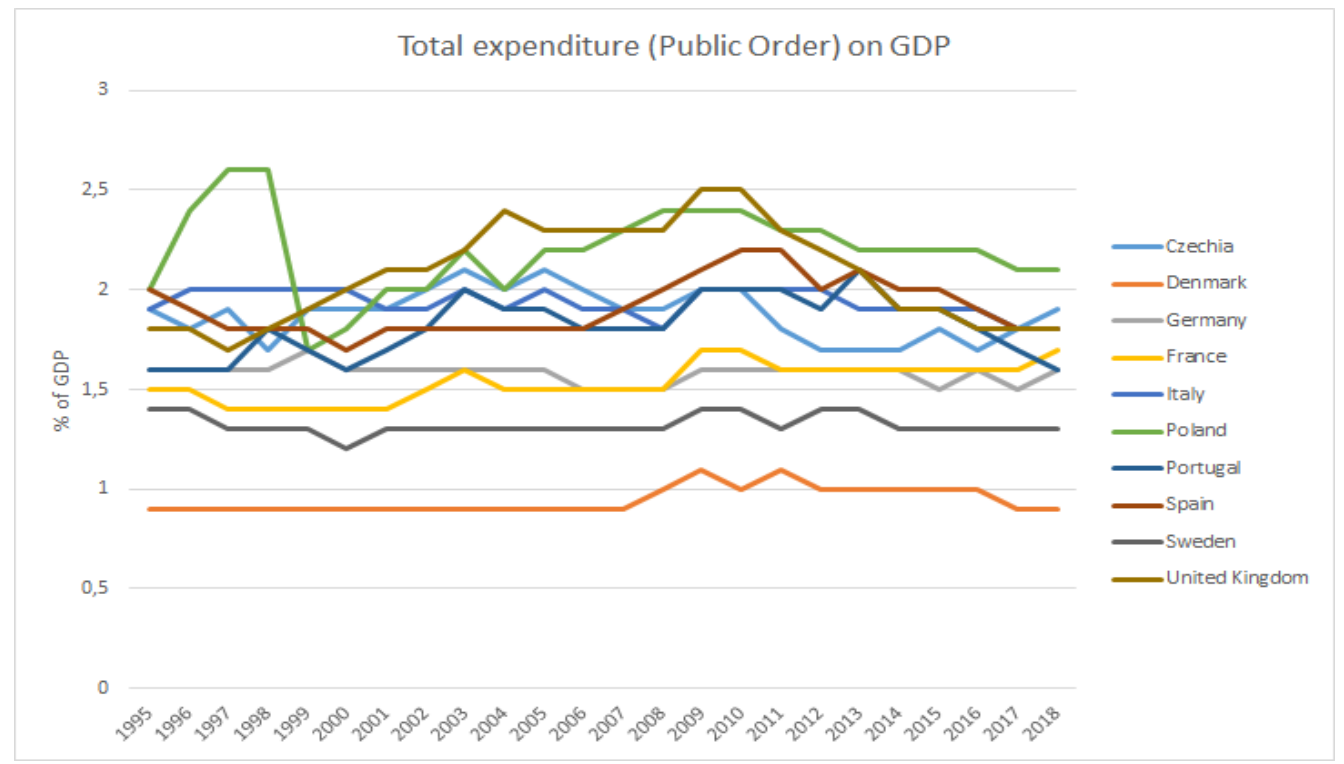

Fig. 9 Public order expenditure as a Share of GDP

Source: own elaboration on data from Eurostat

Public order expenditure (Fig. 9) had a small surge after the crisis but remained almost constant over time across the panel. Terrorist threat rise and attacks have not sensibly touched this voice of expenditure. On the other hand, general trend over defence expenditure (Fig. 11) has been negative over time. Without considering economic growth, it appears that only Poland and France kept a stable level of expenditure with respect of their GDP. Despite a surge after the crisis, even UK approached France in terms of share of expenditures. The greatest share was destined in UK, France and Poland. All other nation devoted less resource relatively to the GDP than Italy, standing at the fourth place with $1.3 \%$. Spain and Portugal present the lowest expenditure share with less than $1 \%$.

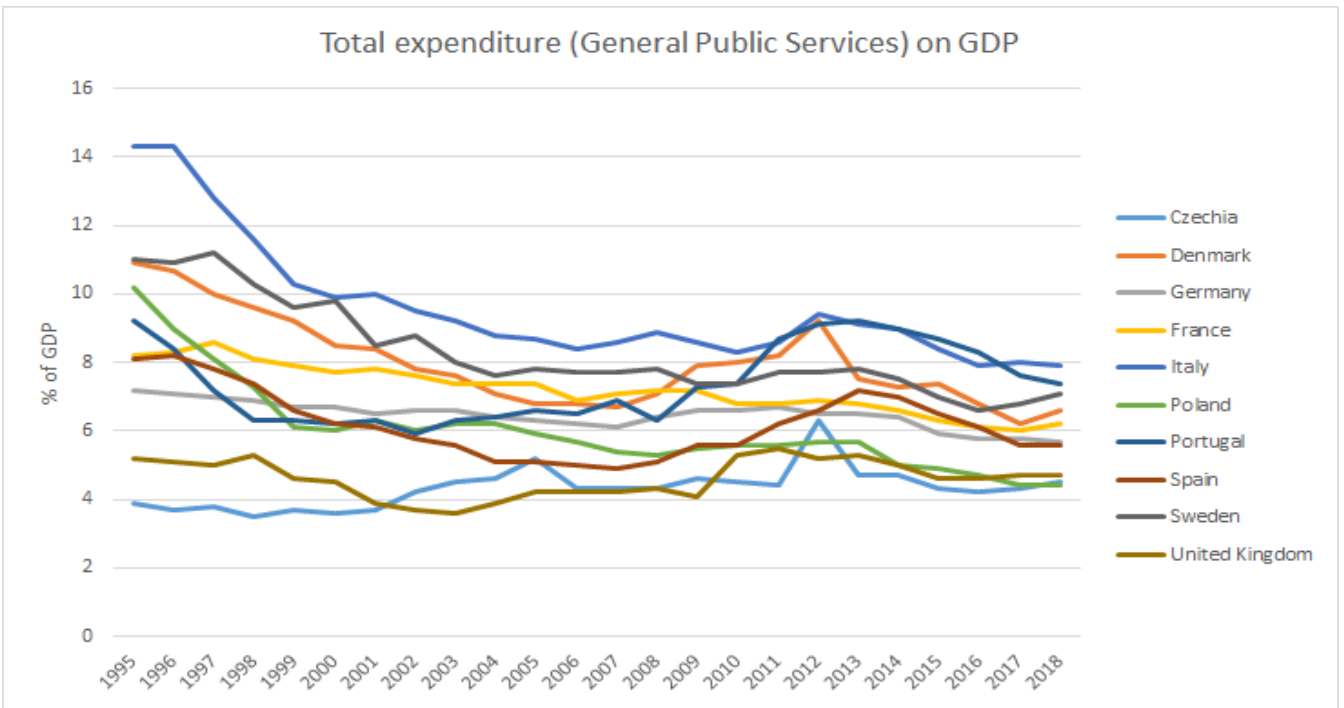

Fig. 10 General Public Service as a Share of GDP

Source: own elaboration on data from Eurostat 
INSIGHTS INTO REGIONAL DEVELOPMENT

ISSN 2669-0195 (online) http://jssidoi.org/jesi/ 2020 Volume 2 Number 4 (December)

http://doi.org/10.9770/IRD.2020.2.4(1)

General Public Services (Fig. 10) display a clear convergence between the greatest payers (Italy) and smallest (Czechia). Such feature is probably related to the adoption of the new currency and the general expenditure revision. Despite the shock around 2008-2009, this expenditure voice did not change sensibly. It appears that convergence pace continued, nevertheless. The greatest response to the crisis with such expenditure where Italy and Denmark, proportionally to the dimension of expenditure then. Altogether to Czechia, Denmark surge in General public expenditures registered lasted only in 2012.

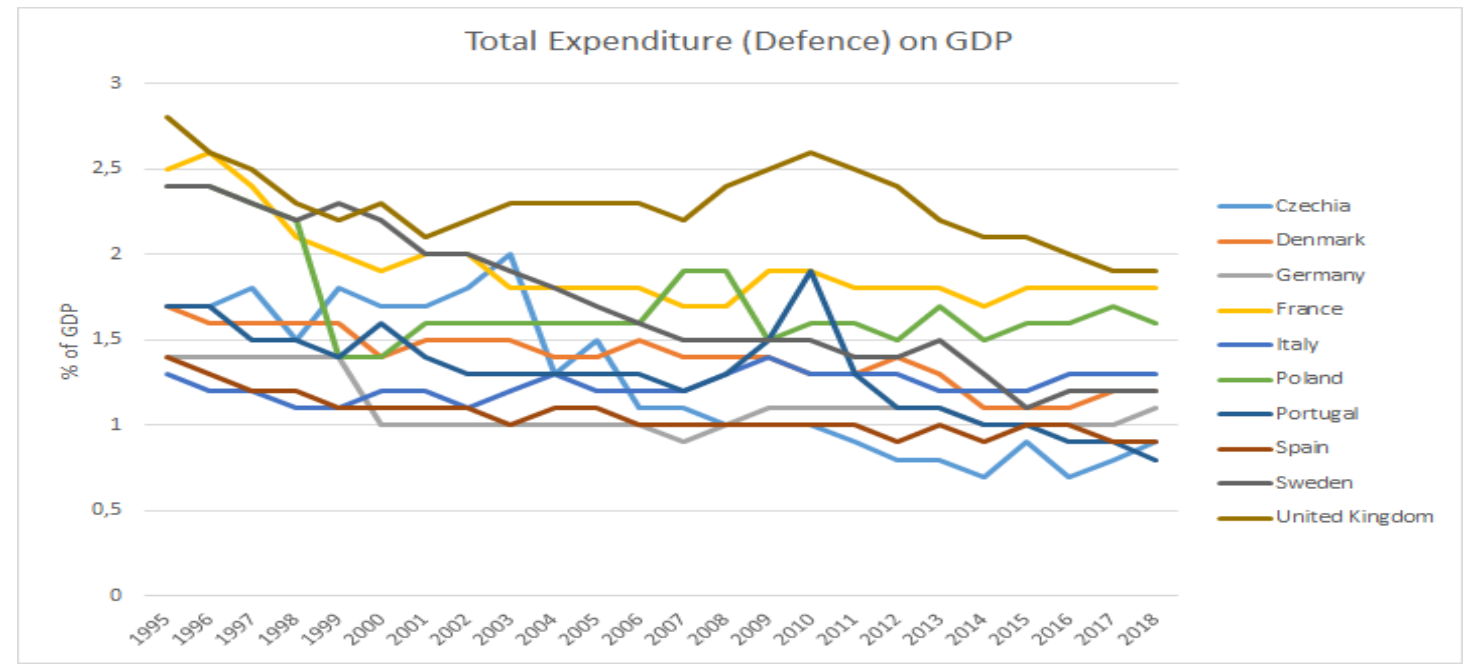

Fig. 11 Defence expenditure as a Share of GDP

Source: own elaboration on data from Eurostat

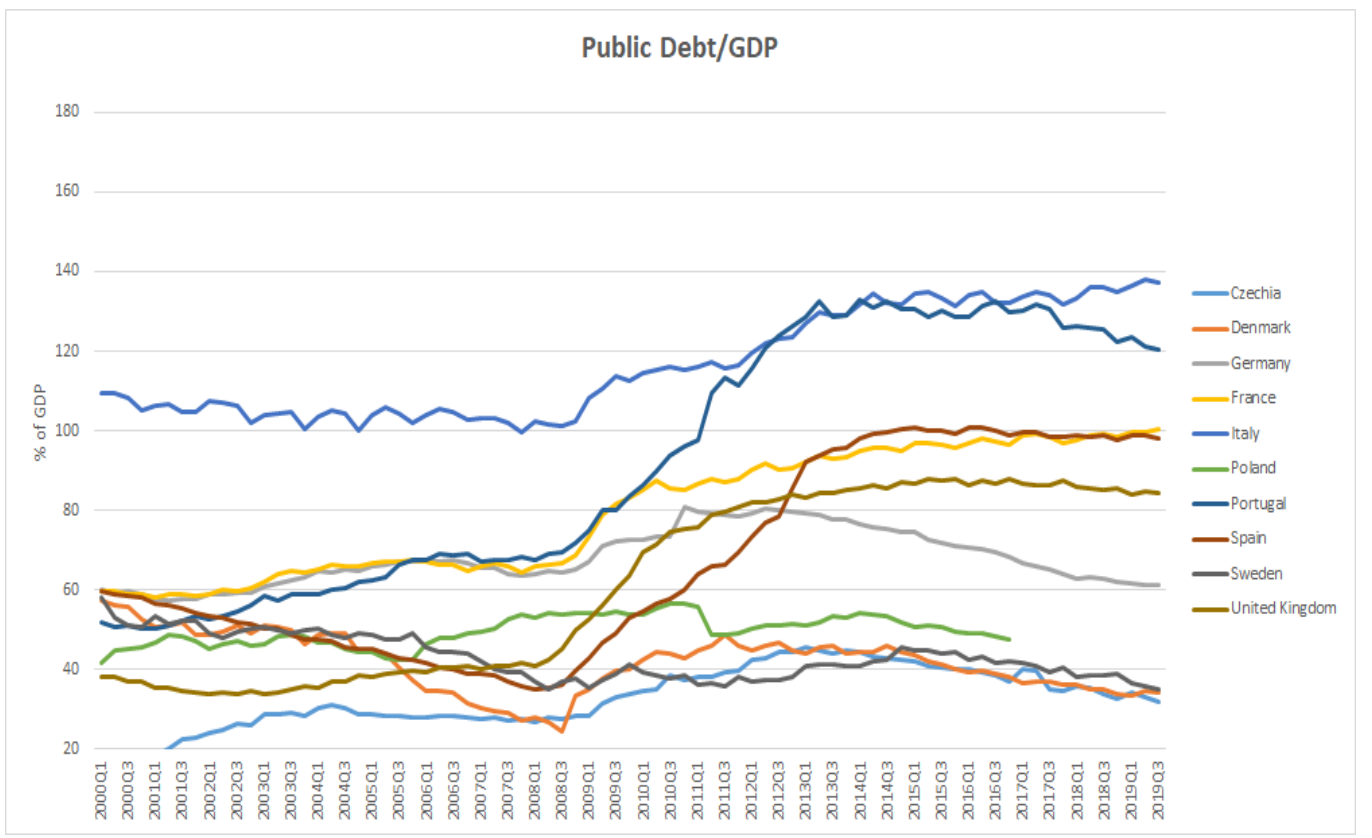

Fig. 12 Public Debt/GDP ratio

Source: own elaboration on data from Eurostat 
INSIGHTS INTO REGIONAL DEVELOPMENT

ISSN 2669-0195 (online) http://jssidoi.org/jesi/ 2020 Volume 2 Number 4 (December) http://doi.org/10.9770/IRD.2020.2.4(1)

Public debt flow and stock indicators express a clear divergence within this panel. In terms of debt, a general stability before the crisis change afterwards. The scenario could be is break down into high (Italy and Portugal), medium (Spain, France and UK) and low debt countries (Germany, Poland, Denmark etc.). This divergence is caused by both growth and deficit pace. Nations that used deficit spending while experiencing low or high growth, had either slow growth of debt (Italy and France) or faster (Portugal, Spain and UK). This is exemplary trivial if considering debt stock jointly with debt flow. Fig 13 display clearly that Spain, UK, France and Portugal used extensively deficit spending. On the other hand, Italy reduced constantly deficit spending since 1995, except for 2009, staying nevertheless below the 3\% ratio. Slow growth penalized the efforts of debt reduction. Efforts of low debt countries were aided by positive economic performances; public balance surplus multiplied the benefits of growth.

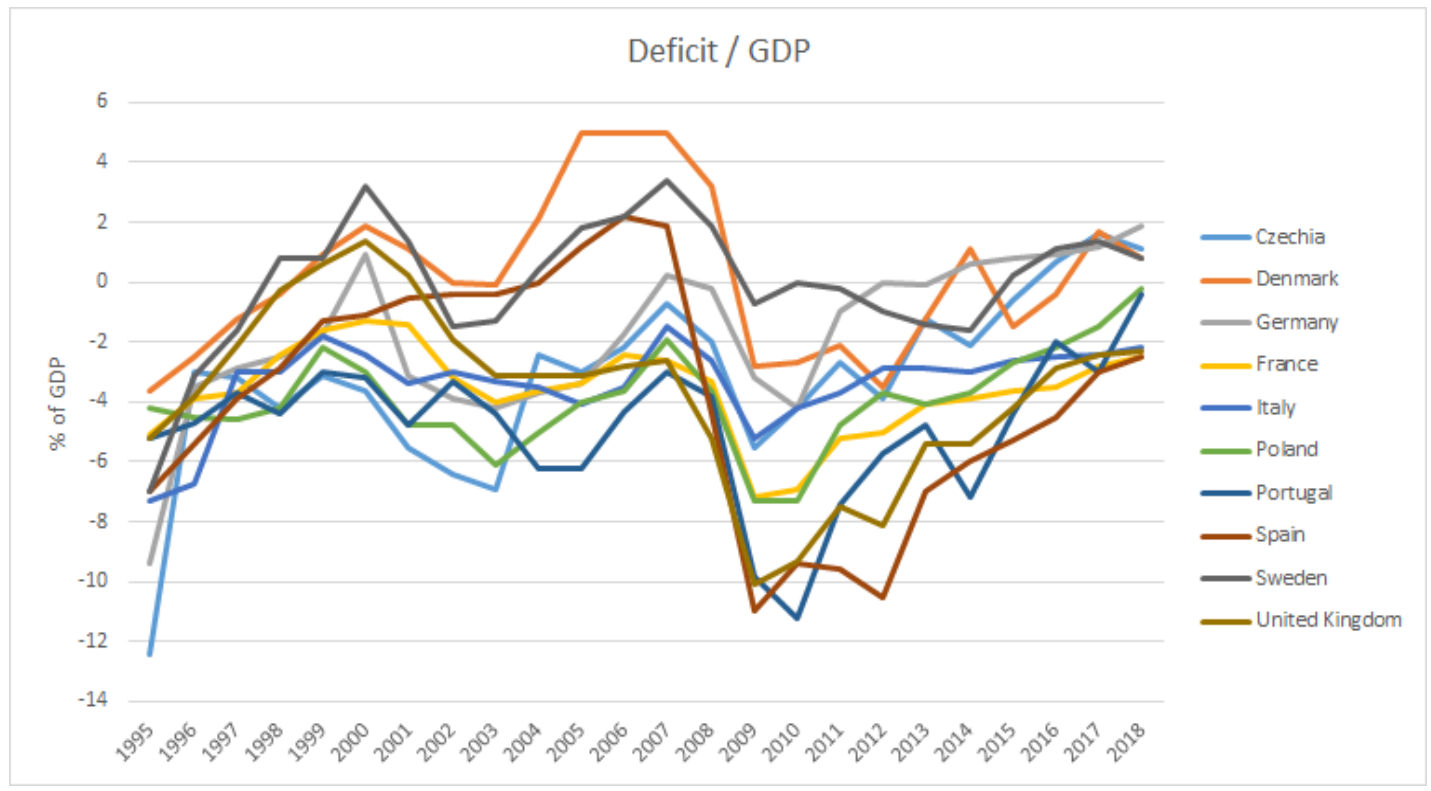

Fig. 13 Public Deficit expenditure/GDP ratio

Source: own elaboration on data from Eurostat

The weight of fiscal revenues on GDP (Fig. 14) remained generally constant over GDP. France and Germany registered sensible change of almost $10 \%$. Italy remained almost constant. The heterogeneity within the panel remained constant between 2005 to 2018. In such sense, only UK strongly reduce tax burden during the crisis, rising slowly the ratio on GDP. The wedge between the highest (Denmark, France) and lowest (UK, Poland) is almost fifteen points of difference. 
INSIGHTS INTO REGIONAL DEVELOPMENT

ISSN 2669-0195 (online) http://jssidoi.org/jesi/ 2020 Volume 2 Number 4 (December)

http://doi.org/10.9770/IRD.2020.2.4(1)

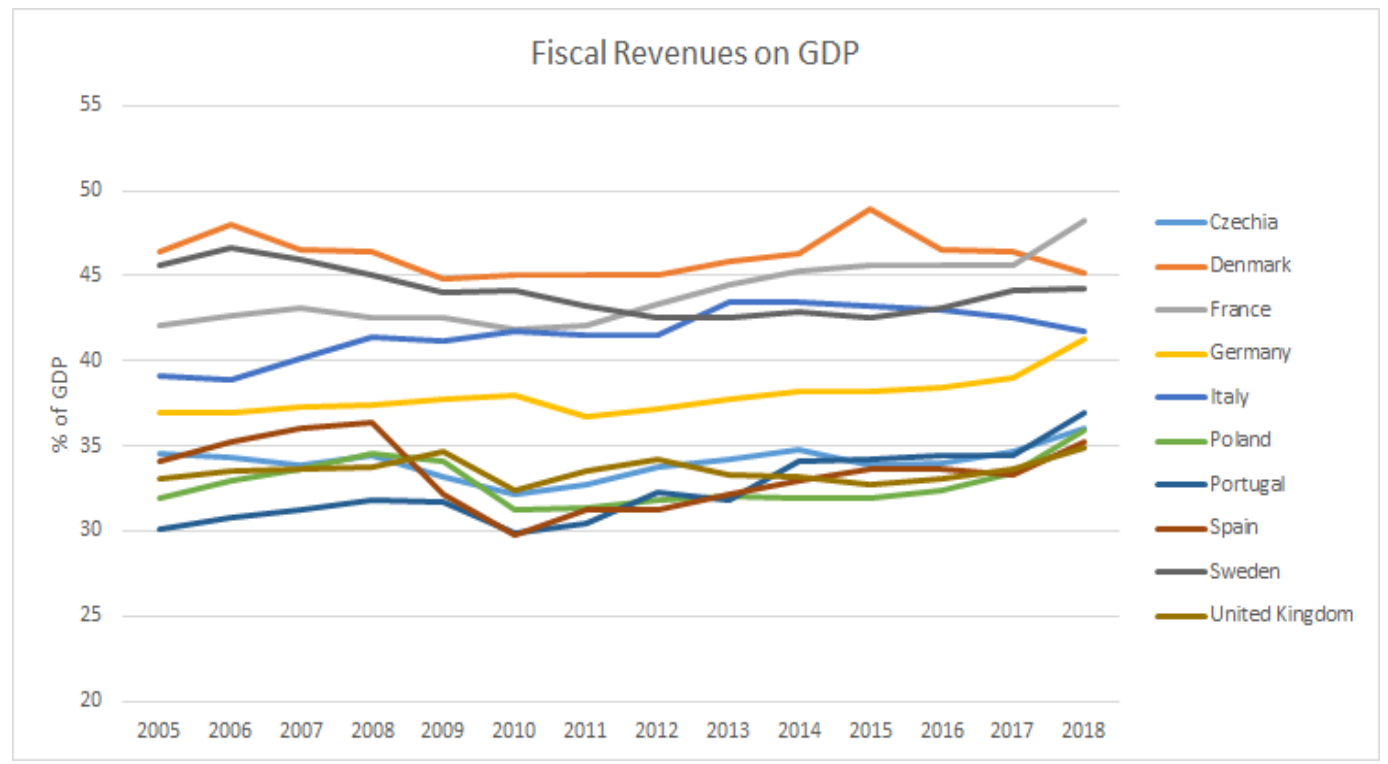

Fig. 14 General Public Service as a Share of GDP

Source: own elaboration on data from Eurostat

\section{B. Per capita expenditure on key macroeconomic variables for growth}

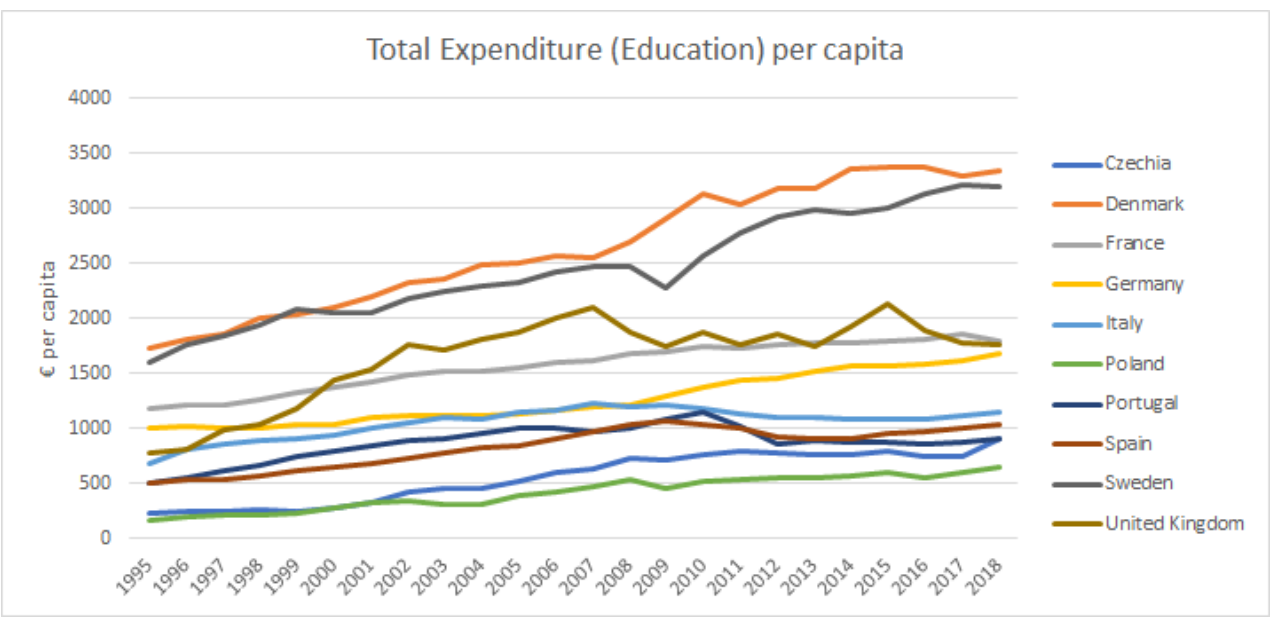

Fig. 15 Total Expenditure Education per capita

Source: own elaboration on data from Eurostat 
INSIGHTS INTO REGIONAL DEVELOPMENT

ISSN 2669-0195 (online) http://jssidoi.org/jesi/ 2020 Volume 2 Number 4 (December)

http://doi.org/10.9770/IRD.2020.2.4(1)

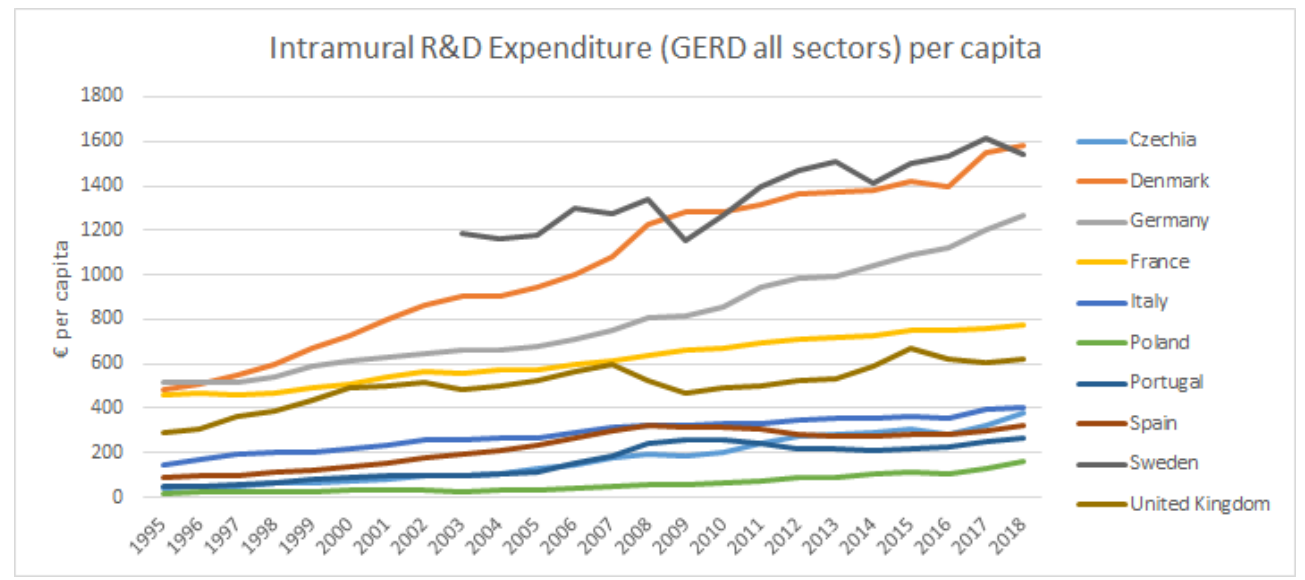

Fig. 16 Intramural Government R\&D Expenditure (GERD) all sectors per capita

Source: own elaboration on data from Eurostat

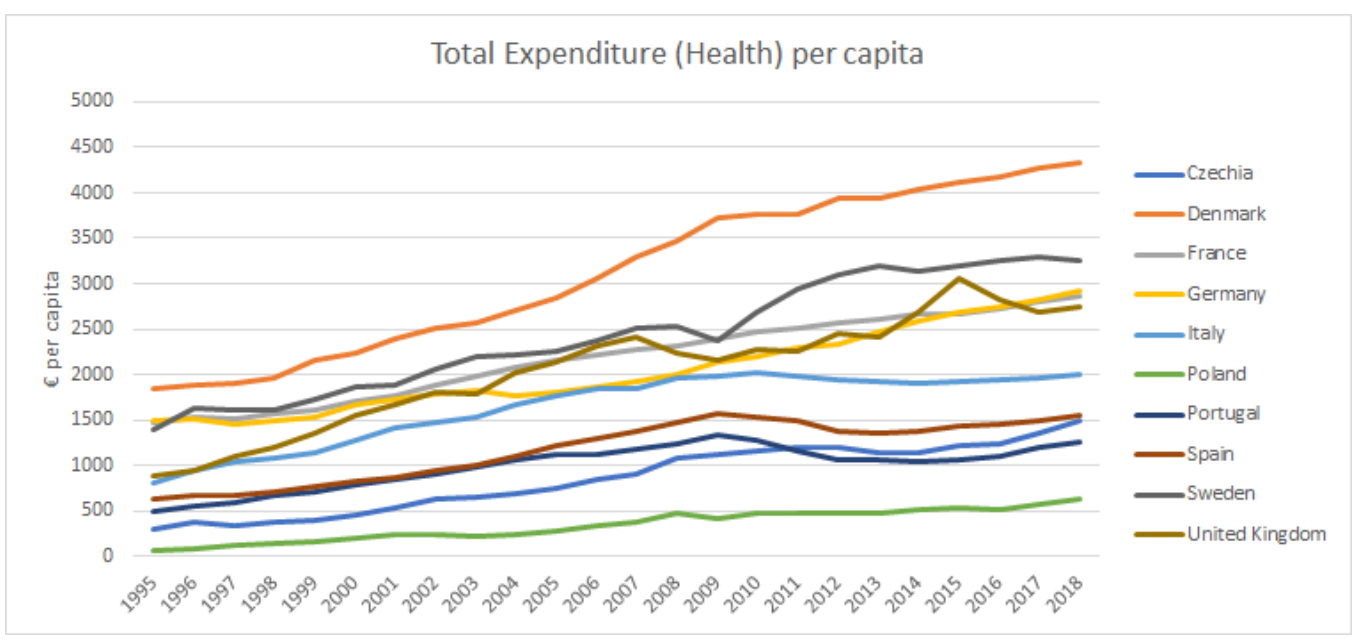

Fig. 17 Total Expenditure Health per capita

Source: own elaboration on data from Eurostat 
INSIGHTS INTO REGIONAL DEVELOPMENT

ISSN 2669-0195 (online) http://jssidoi.org/jesi/ 2020 Volume 2 Number 4 (December)

http://doi.org/10.9770/IRD.2020.2.4(1)

\section{Acknowledgements}

The research is conceptually related to the activities of the European Topic Centre on Waste, materials and the Green Economy (ETC WMGE, European Environment Agency). It is also within the research activitiesof the 2018-2022 UNIFE project on Circular economy, Innovations and SMEs funded by MIUR Italian ministry under the 'Departments of excellence' programme, and the activities of the related CERCIS research centre on Circular Economy, Innovation and SMEs.

All responsibilities remain upon the authors

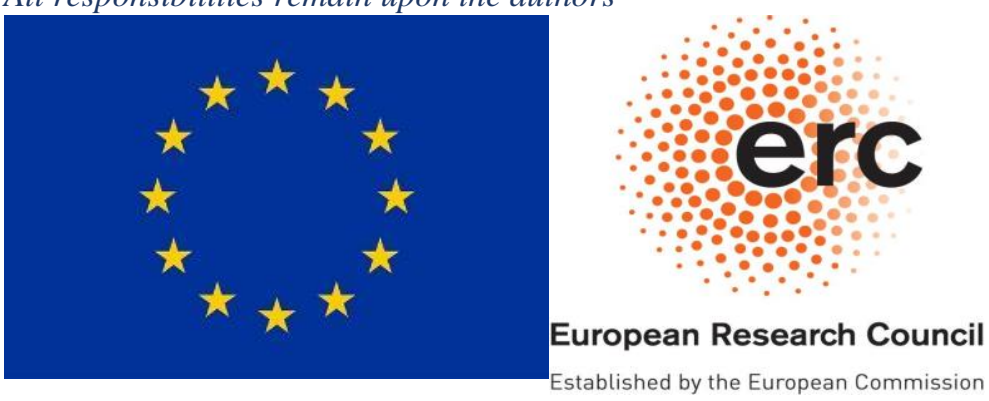

Make your research more visible, join the Twitter account of INSIGHTS INTO REGIONAL DEVELOPMENT:

@IntoInsights

Massimiliano MAZZANTI

ORCID ID: https://orcid.org/0000-0002-6538-7942

Matteo MAZZARANO

ORCID ID: https://orcid.org/0000-0002-6106-1048

Andrea PRONTI

ORCID ID: https://orcid.org/0000-0001-8781-3714

Marco QUATROSI

ORCID ID: https://orcid.org/0000-0002-9409-9608

Register for an ORCID ID:

https://orcid.org/register

Copyright (C) 2019 by author(s) and VsI Entrepreneurship and Sustainability Center

This work is licensed under the Creative Commons Attribution International License (CC BY).

http://creativecommons.org/licenses/by/4.0/

(c) (i) Open Access 